Article

\title{
Synthesis and Structure-Activity Relationships of a Series of Aporphine Derivatives with Antiarrhythmic Activities and Acute Toxicity
}

\author{
Hui Wang, Xin Cheng, Shujun Kong, Zixian Yang, Hongmei Wang, Qiuyan Huang, Jingyu Li, \\ Cheng Chen and Yunshu Ma * \\ Department of Pharmaceutics Science, School of Chinese Materia Medica, Yunnan University of Traditional \\ Chinese Medicine, 1076\#, Yuhua road, Chenggong, Kunming 650000, China; huiwang2016@sina.cn (H.W.); \\ chengxin920@126.com (X.C.); kongshujun1@126.com (S.K.); yangzixian2@126.com (Z.Y.); \\ 15198906044@163.com (H.W.); 15912165160@163.com (Q.H.); lijingyu06@163.com (J.L.); \\ guoke10141@163.com (C.C.) \\ * Correspondence: yunshuma2@126.com; Tel./Fax: +86-871-6591-8230
}

Academic Editor: Maria Emília de Sousa

Received: 18 October 2016; Accepted: 7 November 2016; Published: 28 November 2016

\begin{abstract}
Some aporphine alkaloids, such as crebanine, were found to present arrhythmic activity and also higher toxicity. A series of derivatives were synthesized by using three kinds of aporphine alkaloids (crebanine, isocorydine, and stephanine) as lead compounds. Chemical methods, including ring-opening reaction, bromination, methylation, acetylation, quaternization, and dehydrogenation, were adopted. Nineteen target derivatives were evaluated for their antiarrhythmic potential in the mouse model of ventricular fibrillation (VF), induced by $\mathrm{CHCl}_{3}$, and five of the derivatives were investigated further in the rat model of arrhythmia, induced by $\mathrm{BaCl}_{2}$. Meanwhile, preliminary structure-activity/toxicity relationship analyses were carried out. Significantly, $\mathrm{N}$-acetamidesecocrebanine (1d), three bromo-substituted products of crebanine (2a, 2b, $2 \mathbf{c}), N$-methylcrebanine (2d), and dehydrostephanine (4a) displayed antiarrhythmic effects in the $\mathrm{CHCl}_{3}$-induced model. Among them, $7.5 \mathrm{mg} / \mathrm{kg}$ of $\mathbf{2 b}$ was able to significantly reduce the incidence of $\mathrm{VF}$ induced by $\mathrm{CHCl}_{3}(p<0.05)$, increase the number of rats that resumed sinus rhythm from arrhythmia, induced by $\mathrm{BaCl}_{2}(p<0.01)$, and the number of rats that maintained sinus rhythm for more than $20 \mathrm{~min}(p<0.01)$. Therefore, $\mathbf{2} \mathbf{b}$ showed remarkably higher antiarrhythmic activity and a lower toxicity $\left(\mathrm{LD}_{50}=59.62 \mathrm{mg} / \mathrm{kg}\right.$, mice), simultaneously, indicating that $\mathbf{2} \mathbf{b}$ could be considered as a promising candidate in the treatment of arrhythmia. Structural-activity analysis suggested that variationsin antiarrhythmic efficacy and toxicity of aporphines were related to the $\mathrm{C}-1, \mathrm{C}-2$-methylenedioxy group on ring A, restricted ring B structural conformation, $\mathrm{N}$-quaternization of ring $\mathrm{B}$, levoduction of 6 a in ring $\mathrm{C}$, and the 8-, 9-, 10-methoxy groups on ring $\mathrm{D}$ on the skeleton.
\end{abstract}

Keywords: aporphine derivatives; antiarrhythmia; 10,11-dibromocrebanine; 3-bromocrebanine; crebanine; stephanine

\section{Introduction}

Although radio frequency ablation and other new techniques have been applied in clinical therapy for the treatment of cardiac arrhythmia, drug therapy is still an important and essential method of treatment. According to current methodology of the Vaughan Williams' electrophysiological classification, available anti-arrhythmic drugs are divided into four categories: $\mathrm{Na}^{+}$channel blockers (category I), $\beta$-receptor blockers (category II), $\mathrm{K}^{+}$channel blockers (category III), and $\mathrm{Ca}^{+}$channel blockers (category IV) [1]. Unfortunately, many of the drugs that belong to these four categories have also shown unavoidable side-effects, such as cardiac arrhythmia [2]. However, evidence shows that 
the new category III drugs, working through multiple ion $\left(\mathrm{I}_{\mathrm{kr}}, \mathrm{I}_{\mathrm{ks}}, \mathrm{I}_{\mathrm{to}}, \mathrm{I}_{\mathrm{Na}}\right)$ channels, are likely to become the most prospective candidates for the treatment of arrhythmia, due to their higher efficiency, as well as their lower risk of side-effects [3]. Therefore, searching for new components from natural products and their derivatives that act on multiple ion channels seems to be one of the more important approaches in the development of new antiarrhythmic drugs [4].

In the last 30 years, several aprophine-type compounds, such as isocorydine, L-dicentrine, and crebanine, extracted from plants in the subgenus Tuberiphania Lo et M. Yang and the genus Stephania, Menispermaceae, have been found possessing remarkable antiarrhythmic activities [5-7]. Based on traditional medical records, some species from this subgenus have been used as medicinal herbs for a long time in Southwest China, with medical functions such as pain-relief, heat-clearing, detoxing, and activating blood circulation [8]. Studies have shown that almost all species of this subgenus contain various types of isoquinoline alkaloids, including aprophines, morphinans, protoberberines, etc., which display extensive physiological activities. They show activity on the $\mathrm{K}^{+}, \mathrm{Ca}^{2+}$, and $\mathrm{Na}^{+}$ channel, and some of them have been reported to be blockers of 5-hydroxytryptamine and dopamine receptors [9]. Meanwhile, isoquinoline alkaloids, for example, berberine, $l$-tetrahydropalmatine, and isocorydine, have been used in clinical treatment of cardiovascular and cranial disease in China. The functions on multiple $\mathrm{K}^{+}, \mathrm{Ca}^{2+}$, and $\mathrm{Na}^{+}$ion channels that these alkaloids exhibit coincides with the current leading trend in the screening of new category III anti-arrhythmic drugs [10-12]. In our previous observations, crebanine, an aprophine type alkaloid, showed a higher anti-arrhythmic effect on experimental arrhythmia models compared with isocroydine and L-dicentrine [13]; however, it was also found that the acute toxicity of crebanine was higher than that of isocroydine and L-dicentrine. The effective arrhythmia dosage $(2.5 \sim 5.0 \mathrm{mg} / \mathrm{kg})$ of crebanine was close to its $\mathrm{LD}_{50}(9.38 \mathrm{mg} / \mathrm{kg}) \mathrm{in}$ mice [14], which implies that crebanine has a relatively narrow therapeutic window.

The present study is a further investigation regarding the structural modification and evaluation of the arrhythmic activities of aprophine alkaloids. The authors have attempted to find new aprophine derivatives with higher antiarrhythmia efficiencies and lower toxicities. A series of derivatives from three kinds of aporphine (crebanine, isocroydine, and stephanine) were designed and synthesized by connecting specific pharmacophores to enlarge the target distribution of antiarrhythmia. At the same time, hydrophobic groups or lipophilic groups were introduced in order to improve the lipid-water partition coefficient and membrane permeability. The antiarrhythmic effects of the derivatives were preliminarily evaluated in a mouse model of ventricular fibrillation (VF), induced by $\mathrm{CHCl}_{3}$, and further confirmed in a rat model of arrhythmia, induced by $\mathrm{BaCl}_{2}$. Six derivatives were obtained, and are reported here for the first time, with antiarrhythmic effects and the structure-activity relationships are discussed.

\section{Results and Discussion}

Nineteen products, including 13 derivatives of crebanine, four derivatives of isocorydine, and two derivatives of stephanine, were synthesized, isolated, purified, and identified (Schemes 1-5), of which 11 are reported for the first time: Secocrebanine (1a), N-cyclopropylmethylsecocrebanine (1b), N-trifluoroacetamidesecocrebanine (1c), N-acetamidesecocrebanine (1d), $N$-methylsulfonamidesecocrebanine (1e), 3,10,11-Tribromocrebanine (2a), 10,11-Dibromocrebanine (2b), 3-Bromocrebanine (2c), 11-Methoxy-N-methylisocorydine (5a), 11-Methoxyisocorydine (5b), and 11-Ethoxyisocorydine (5c). 


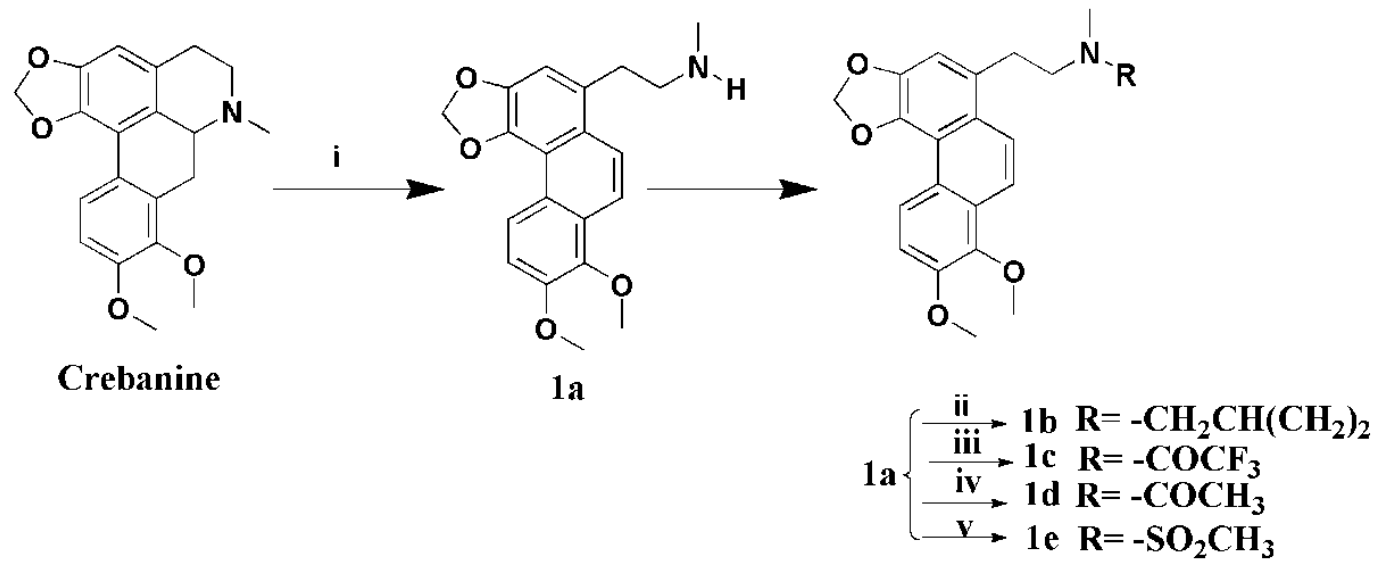

Scheme 1. Synthesis of crebanine derivatives $\mathbf{1 a}, \mathbf{1} \mathbf{b}, \mathbf{1 c}, \mathbf{1 d}$, and $\mathbf{1 e}$. Reagents and conditions: (i) 1-chloroethyl chloroformate, $\mathrm{K}_{2} \mathrm{CO}_{3}, 1,2-\mathrm{CH}_{2} \mathrm{ClCH}_{2} \mathrm{Cl}, 85^{\circ} \mathrm{C}, 6 \mathrm{~h}, \mathrm{MeOH}, 37 \% \mathrm{HCl}$, refluxed for $2 \mathrm{~h}$; (ii) cyclopropylmethyl bromide, $\mathrm{K}_{2} \mathrm{CO}_{3}, \mathrm{MeCN}, 80^{\circ} \mathrm{C}, 4 \mathrm{~h}$; (iii) trifluoroacetic anhydride, $\mathrm{Et}_{3} \mathrm{~N}$, anhydrous $\mathrm{CH}_{2} \mathrm{Cl}_{2}, 2 \mathrm{~h}$, r.t.; (iv) acetic anhydride, 4-dimethylaminopyridine, $\mathrm{Et}_{3} \mathrm{~N}$, anhydous $\mathrm{CH}_{2} \mathrm{Cl}_{2}$, r.t., 4 h; and (v) methanesulfonyl chloride, $\mathrm{Et}_{3} \mathrm{~N}$, anhydrous $\mathrm{CH}_{2} \mathrm{Cl}_{2}$, r.t., 2 h.<smiles>COc1ccc2c(c1OC)CC1c3c(cc4c(c3-2)OCO4)CCN1C</smiles>

Crebanine

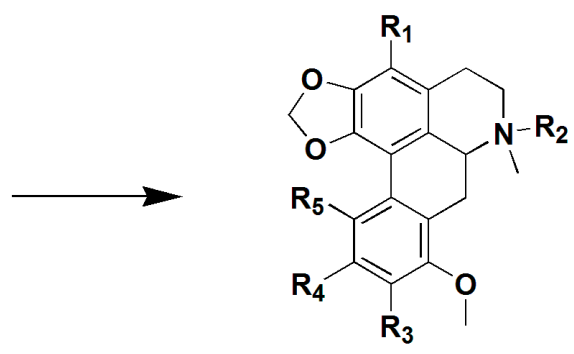

(i) $2 \mathrm{a} \mathrm{R}_{1}=-\mathrm{Br} \quad \mathrm{R}_{3}=-\mathrm{OCH}_{3} \quad \mathrm{R}_{4}=-\mathrm{Br}$

(i) $2 b \quad R_{1}=-H \quad R_{3}=-O_{3} \quad R_{4}=-B r$

(i) $2 c \quad R_{1}=-B r \quad R_{3}=-\mathrm{OCH}_{3} \quad R_{4}=-\mathrm{H}$

$\mathbf{R}_{5}=-\mathrm{Br}$

$\mathbf{R}_{5}=-\mathrm{Br}$

(ii) $2 d \mathbf{R}_{1}=-\mathrm{H} \quad \mathrm{R}_{2}=-\mathrm{CH}_{3}$

$\mathrm{R}_{3}=-\mathrm{OC} \mathrm{CH}_{3} \mathrm{R}$

(iii) $2 \mathrm{e} \mathbf{R}_{1}=-\mathbf{H}$

$\mathbf{R}_{3}=-\mathrm{OH}$

$\mathbf{R}_{\mathbf{4}}=-\mathbf{H}$

$\mathbf{R}_{5}=-\mathrm{H}$

$\mathbf{R}_{4}=-\mathbf{H} \quad \mathbf{R}_{5}=-\mathbf{H}$

Scheme 2. Synthesis of crebanine analogues $\mathbf{2 a}, \mathbf{2 b}, \mathbf{2 c}, \mathbf{2 d}$, and $\mathbf{2 e}$. Reagents and conditions: (i) $\mathrm{N}$-Bromosuccinimide, trifluoroacetic acid, r.t., $18 \mathrm{~h}$; (ii) ether, $\mathrm{CH}_{3} \mathrm{I}, \mathrm{MeOH}$, r.t., $16 \mathrm{~h}$; and (iii) $\mathrm{AlBr}_{3}$, anhydrous $\mathrm{CH}_{2} \mathrm{Cl}_{2}$, nitrobenzene, $5{ }^{\circ} \mathrm{C}$, argon, $18 \mathrm{~h}$.
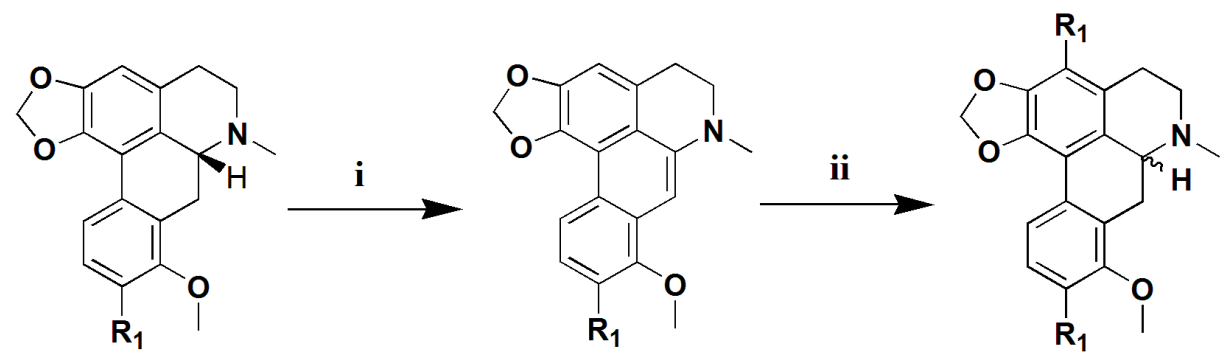

(-)Crebanine $\mathbf{R}_{1}=-\mathrm{OCH}_{3}$

$$
\begin{aligned}
& 3 a R_{1}=-\mathrm{OCH}_{3} \\
& 4 a R_{1}=-H
\end{aligned}
$$$$
3 b \mathbf{R}_{1}=-\mathrm{OCH}_{3}
$$$$
\text { (-)Stephanine } \mathbf{R}_{1}=-\mathbf{H}
$$

$4 b \mathbf{R}_{1}=-\mathbf{H}$

Scheme 3. Synthesis of crebanine and stephanine derivatives $3 \mathbf{a}, 3 \mathbf{b}, \mathbf{4} \mathbf{a}$ and $\mathbf{4 b}$. Reagents and conditions: (i) $10 \% \mathrm{Pd} / \mathrm{C}, \mathrm{MeCN}, \mathrm{N}_{2}$, refluxed for 6 h; and (ii) $\mathrm{NaCNBH}_{3}, \mathrm{EtOH}, 2 \mathrm{NHCl}$, r.t., 18 h. 
<smiles>COc1ccc2c(c1O)-c1c(ccc(OC)c1OC)CC2C</smiles><smiles>[R]c1c(OC)c(OC)cc2c1-c1c(ccc(OC)c1[R2])N(C([R1])C)CC2</smiles>

\section{Isocorydine}

(i) $5 \mathrm{a} \mathrm{R}_{1}=-\mathrm{CH}_{3} \quad \mathrm{R}_{2}=-\mathrm{OCH}_{3}$

(ii) $5 \mathrm{~b} \mathrm{R} \mathbf{R}_{2}=-\mathrm{OCH}_{3}$

(iii) $5 \mathrm{c} \mathrm{R} \mathrm{R}_{2}=-\mathrm{OCH}_{2} \mathrm{CH}_{3}$

(iv) $5 d \mathrm{R}_{1}=-\mathrm{CH}_{3} \quad \mathrm{R}_{2}=-\mathrm{OH}$

Scheme 4. Synthesis of isocorydine derivatives $\mathbf{5 a}, \mathbf{5 b}, \mathbf{5 c}$, and $\mathbf{5 d}$. Reagents and conditions: (i) Tetrabutylammonium bromide, $\mathrm{K}_{2} \mathrm{CO}_{3}$, anhydrous $\mathrm{THF}, \mathrm{CH}_{3} \mathrm{I}$, r.t., 8 h; (ii) $\mathrm{N}$, $\mathrm{N}$-diisopropylethylamine, trimethylsilyldiazomethane, $\mathrm{MeCN}, \mathrm{MeOH}, 15$ h, r.t.; and (iii) Tetrabutylammonium bromide, $\mathrm{K}_{2} \mathrm{CO}_{3}$, anhydrous THF, $\mathrm{CH}_{3} \mathrm{CH}_{2} \mathrm{I}$, r.t., 8 h; and (iv) ether, $\mathrm{CH}_{3} \mathrm{I}, \mathrm{MeOH}$, r.t., 16 h.

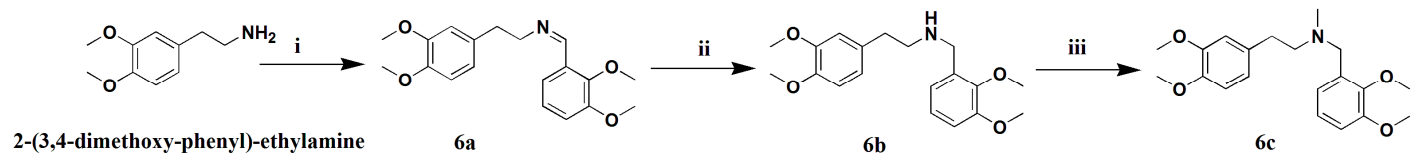

Scheme 5. Synthesis of crebanine analogues 6c. Reagents and conditions: (i) 2,3-dimethoxy-benzoic acid , methylbenzene, $120^{\circ} \mathrm{C}, 8 \mathrm{~h}$; (ii) $5 \% \mathrm{Pd} / \mathrm{C}, \mathrm{MeOH}, \mathrm{H}_{2}, 1$ bar, $8 \mathrm{~h}$; and (iii) $\mathrm{K}_{2} \mathrm{CO}_{3}$, anhydrous THF, CHI, r.t., 4 h.

The antiarrhythmic activities of the 19 products, respectively, were tested in the mouse model of ventricular fibrillation (VF), induced by $\mathrm{CHCl}_{3}$. Six compounds, $\mathbf{1 d}, \mathbf{2 a}, \mathbf{2 b}, \mathbf{2 c}, \mathrm{N}$-methylcrebanine (2d), and dehydrostephanine (4a), were found to possess significant antiarrhythmic effects $(p<0.05)$ (Figure 1A-D). Furthermore, in the rat model of arrhythmia, induced by $\mathrm{BaCl}_{2}, \mathbf{2 a}, \mathbf{2 b}, \mathbf{2} \mathbf{c}, \mathbf{2 d}$, and $4 \mathbf{a}$ demonstrated significant antiarrhythmia activity (Table 1). Lastly, in order to evaluate toxicity, the $\mathrm{LD}_{50}$ of three active compounds, two bromo-substituted products of crebanine $(\mathbf{2} \mathbf{a}, \mathbf{2} \mathbf{b})$ and $\mathrm{N}$-methylcrebanine (2d), were calculated using the sequential method in mice (Table 2) as 59.62, 65.15, and $6.432 \mathrm{mg} / \mathrm{kg}$, respectively.

Table 1. Antiarrhythmic activity of fiveaporphine derivatives (2a-d and $4 \mathbf{a})$ in the model of arrhythmia, induced by $\mathrm{BaCl}_{2}$ in anesthetized SD rats (iv) $(n=10)$.

\begin{tabular}{|c|c|c|c|c|c|c|}
\hline Compounds & $\begin{array}{l}\text { Dose } \\
\text { (mg/kg) }\end{array}$ & $\begin{array}{l}\text { Numbers of Rat } \\
\text { Recovering }\end{array}$ & $\begin{array}{l}\text { Recovery } \\
\text { Time (s) }\end{array}$ & $\begin{array}{l}\text { Numbers of Rat } \\
\text { Maintaining } \\
\text { Time } \geq 3 \mathrm{~min}\end{array}$ & $\begin{array}{l}\text { Numbers of Rat } \\
\text { Maintaining } \\
\text { Time } \geq 5 \mathrm{~min}\end{array}$ & $\begin{array}{l}\text { Numbers of Rat } \\
\text { Maintaining } \\
\text { Time } \geq 20 \mathrm{~min}\end{array}$ \\
\hline NS & - & 0 & - & 0 & 0 & 0 \\
\hline Lidocaine & 5 & $7^{* *}$ & $22.2 \pm 8.0$ & $6 * *$ & 2 & 1 \\
\hline Stephanine & 5 & $7^{* *}$ & $35.0 \pm 8.1$ & $6^{* *}$ & $4^{*}$ & 3 \\
\hline Isocorydine & 10 & $9^{* *}$ & $736.4 \pm 489.1$ & $8^{* *}$ & $8^{* *}$ & $4^{*}$ \\
\hline 3,10,11-Tribromocrebanine (2a) & 15 & $7^{* *}$ & $125.5 \pm 145.9$ & 2 & 1 & 0 \\
\hline 10,11-Dibromocrebanine $(\mathbf{2 b})$ & 7.5 & $8^{* *}$ & $113.5 \pm 136.8$ & $8^{* *}$ & $7 * *$ & $5^{* *}$ \\
\hline Dehydrostephanine (4a) & 5 & 10 ** & $23.0 \pm 11.0$ & 0 & 0 & 0 \\
\hline
\end{tabular}

The chi-square test was used to estimate the significance between the numbers of rat recovering and the numbers of rat maintaining time $\geq 3 \mathrm{~min}, 5 \mathrm{~min}$, and $20 \mathrm{~min}$ in all comparisons. Significantly different from the control group, ${ }^{*} p<0.05,{ }^{* *} p<0.01$. Values of recovery time are expressed as mean $\pm \mathrm{SD}$. SD represents standard deviation. 

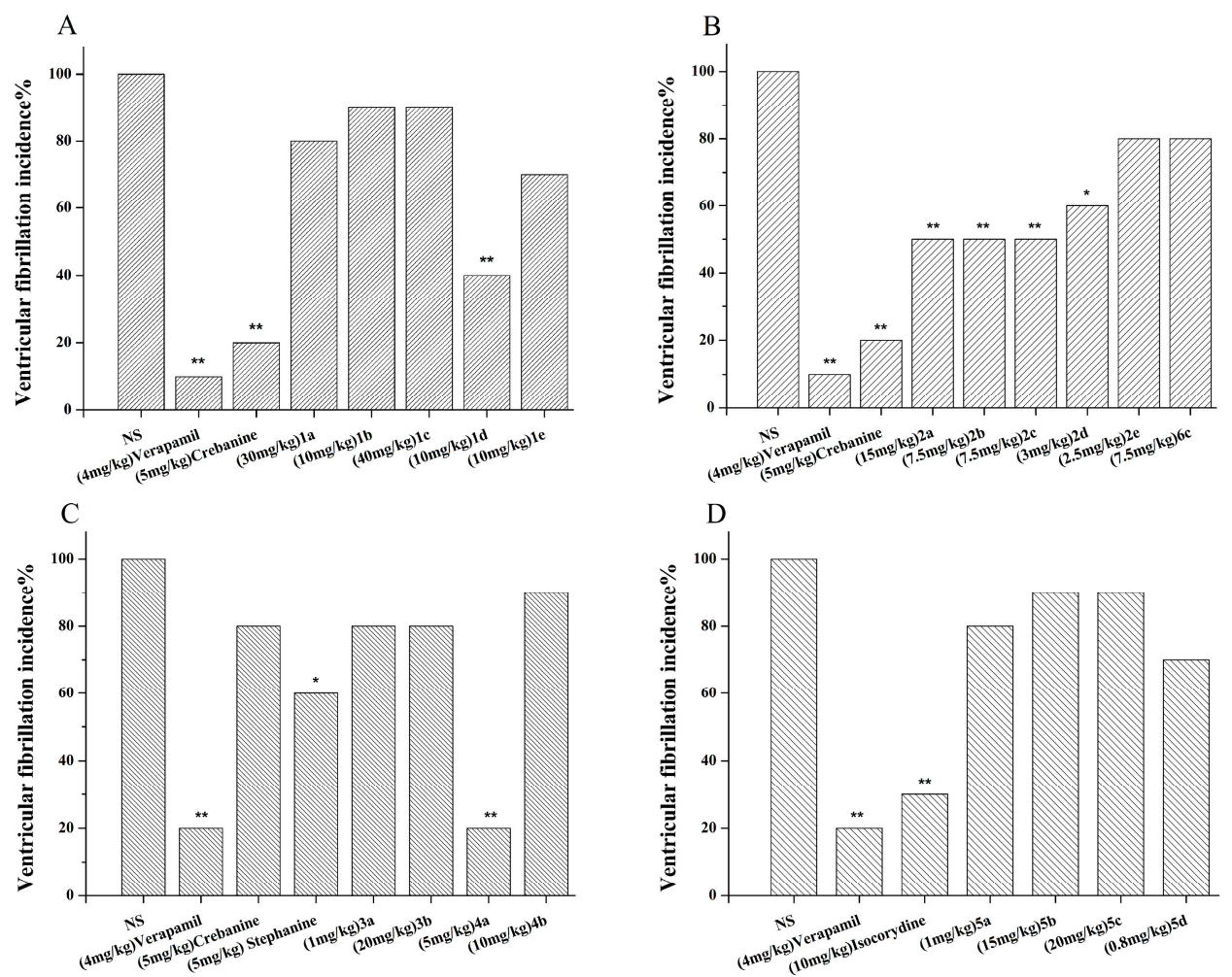

Figure 1. (A-D) Antiarrthymic activity of 19 aporphine derivatives in a mouse VF model, induced by $\mathrm{CHCl}_{3}(n=10)$. Data represent the incidence percentage of VF in 10 experiments. Significantly different from the control group, ${ }^{*} p<0.05,{ }^{* *} p<0.01$. 1d, 2a, 2b, 2c, $\mathbf{2 d}$, and $4 \mathbf{4 a}$ possess significant antiarrhythmic effects.

Table 2. Acute toxicity tests of three crebanine derivatives $(\mathbf{2} \mathbf{b}, \mathbf{2} \mathbf{c}$, and $\mathbf{2} \mathbf{d})$ in mice $(n=10)$.

\begin{tabular}{ccc}
\hline Compounds & LD $_{\mathbf{5 0}}(\mathbf{m g} / \mathbf{k g})$ & $\mathbf{9 5 \%}$ Confidence Intervals (CIs) \\
\hline 10,11-Dibromocrebanine (2b) & 59.62 & $62.23,57.01$ \\
3-Bromocrebanine (2c) & 65.15 & $66.28,64.02$ \\
N-methylcrebanine (2d) & 6.43 & $7.53,5.34$ \\
Crebanine [14] & 9.38 & $8.24,10.53$ \\
\hline
\end{tabular}

\subsection{Opening up of the N-C Bondon Ring B and N-Substitution and Antiarrhythmic Activity/Toxicity}

Previously, we characterized some new type III anti-arrhythmic drugs, such as dronedarone [15], most of which contained the $N$-substitution structure [3]. Therefore, we presumed that the $\mathrm{N}$-substitution in ring B of aporphine might be one of the key reasons for their anti-arrhythmic activities. Five phenanthrene compounds were synthesized (Scheme 1) by opening up the N-C bond (1a) on ring $\mathrm{B}$ of crebanine, further connecting the $\mathrm{N}$ position with four kinds of lipophilic groups (1b-1e). The five obtained analogues were tested in the mouse model of $\mathrm{VF}$, induced by $\mathrm{CHCl}_{3}$ (Figure 1A). The result showed that, except for compound $1 \mathbf{d}(10 \mathrm{mg} / \mathrm{kg})$, which was able to return the occurrence of VF to a normal sinus rhythm in $60 \%$ of tested mice $(p<0.01)$ (Figure 1A), the remaining four ring B-opening derivatives $(\mathbf{1 a}, \mathbf{1} \mathbf{b}, \mathbf{1} \mathbf{c}$, and $\mathbf{1 e})$ showed no significant effects on inhibiting rapid VF in mice, even though the test dosages (10-40 mg/ $\mathrm{kg}$ ) were up to eight times higher than the dosage of crebanine $(5 \mathrm{mg} / \mathrm{kg}$ ). Simultaneously, the tested mice also showed no obvious toxic symptoms. These results indicate that antiarrhythmic efficiency and toxicity were both decreased when ring B of crebanine was opened up. Therefore, it is speculated that a proper, closed ring B structure of aporphine was necessary, as the flat structure of the restricted ring B structural conformation could embed into myocardial cells more easily than the ring B-opening structure of phenanthrenes. 


\subsection{The Lipophilicity/Hydrophilicity of Crebanine Derivatives and Antiarrhythmic Activity/Toxicity}

Bromo-substituted derivatives often increase the lipophilicity of compounds. Bromine atoms were first introduced into the structure of crebanine (Scheme 2) to explore the relationship between lipophilicity and the antiarrhythmic activity/toxicity of aporphines. Compared with normal saline, compounds $\mathbf{2 a}, \mathbf{2} \mathbf{b}$, and $\mathbf{2 c}$, three kinds of crebanine bromoderivatives, exhibited a remarkable recovery in mouse VF $(p<0.05)$ (Figure 1B). Notably, dibromide $\mathbf{2} \mathbf{b}$ of crebanine displayed better antiarrhythmic activity than tribromide of crebanine $2 \mathbf{a}$ and monobromide of crebanine $2 \mathrm{c}$ (Table 1). After a $7.5 \mathrm{mg} / \mathrm{kg}$ dosage of $\mathbf{2} \mathbf{b}$ was given, the number of animals that recovered, and the number of animals maintaining sinus rhythm $\geq 20 \mathrm{~min}$ was obviously higher than those of $\mathbf{2 a}(15 \mathrm{mg} / \mathrm{kg})$ and $\mathbf{2 c}(7.5 \mathrm{mg} / \mathrm{kg})$ in the rat model of arrhythmia, induced by $\mathrm{CHCl}_{3}$ (Figure 1B). The results indicate that the different numbers of $\mathrm{Br}$ replacements varied the lipid solubility of crebanine and changed the level of antiarrhythmic efficiency. Furthermore, the $\mathrm{LD}_{50}$ of $\mathbf{2 c}(65.15 \mathrm{mg} / \mathrm{kg})$ and $\mathbf{2 b}(59.62 \mathrm{mg} / \mathrm{kg})$ in mice (Table 2) were much higher than that of crebanine $\left(\mathrm{LD}_{50} 9.38 \mathrm{mg} / \mathrm{kg}\right.$ ) [14], which showed that toxicity of brominated crebanine was much lower than that of crebanine. This predicts that brominated crebanine may be a prospective modified structure and would serve as a lead compound for antiarrhythmia.

On the other hand, $\mathrm{N}$-methylation (quaternization) was introduced into the structure of crebanine in order to determine how the improvement of hydrophilicity in aporphines impacted the antiarrhythmic activity and toxicity. The quaternary ammonium of crebanine (2d, Scheme 2) displayed a notable antiarrhythmic effect, even at a lower dosage of $3 \mathrm{mg} / \mathrm{kg}$ (Figure 1B), but the tested mice showed symptoms such as polypnea, mydriasis, leaping, and tremors until death, which indicate toxicity of the central nervous system (CNS) and the motor nervous system [16]. The $\mathrm{LD}_{50}$ of $\mathbf{2 d}$ was calculated to be $6.432 \mathrm{mg} / \mathrm{kg}$ in mice (Table 2), much lower than that of crebanine $(9.382 \mathrm{mg} / \mathrm{kg}$ ), which indicated that $\mathrm{N}$-quaternizated aporphines could maintain anti-arrhythmic activity, but that the toxicity was increased at the same time.

\subsection{Ring D O-Demethylation and Antiarrhythmic Activity}

The experiments were designed to remove the $O$-methyl groups in ring $\mathrm{D}$ of crebanine in order to acquire more aporphine derivatives (Scheme 2). Table 3 shows all of reactions and their derivatives [17-22]. Since ring B was unstable and easy to open using strong acids, it was difficult to cleave the $\mathrm{O}$-methyl groups in ring $\mathrm{D}$ when only strong acids $\left(48 \% \mathrm{HBr} / \mathrm{CH}_{3} \mathrm{COOH}, 48 \% \mathrm{HBr}\right.$, and $\mathrm{IH}$ ) were used [17-19]. Otherwise, when crebanine was treated with $\mathrm{BBr}_{3}$ in dichloromethane, a molecular ion peak of the products was observed at $m / z 300[\mathrm{M}+\mathrm{H}]^{+}$, which implies that both the $O$-methyl groups and methylenedioxy of crebanine had been removed simultaneously. Meanwhile, the target product of the four phenolic hydroxyl groups was not acquired due to its high hydrophilicity and instability. A 9-demethyl group derivative, namely stesakine (2e, Scheme 2) [20] in Table 3, was obtained by utilizing the Lewis acids, $\mathrm{BCl}_{3}$, and $\mathrm{AlBr}_{3}$ [21,22], which indicated that the 9-methoxy group in ring $\mathrm{D}$ of crebanine was less stable than the 8-methoxy group.

Table 3. O-Demethylation reaction of crebanine.

\begin{tabular}{cccccc}
\hline Entry & Solvent & Temperature $\left({ }^{\circ} \mathbf{C}\right)$ & Time (h) & Product & Yield (\%) \\
\hline 1 & $48 \% \mathrm{HBr}$ & 120 & 3.5 & - & - \\
2 & $48 \% \mathrm{HBr} / \mathrm{CH}_{3} \mathrm{COOH}$ & 130 & 4 & $\mathbf{1 d}$ & 70 \\
3 & $\mathrm{HI}$ & 100 & 2 & - & - \\
4 & $\mathrm{BBr}_{3} / \mathrm{CH}_{2} \mathrm{Cl}_{2}$ & 25 & 3 & - & - \\
5 & $\mathrm{BCl}_{3} / \mathrm{CH}_{2} \mathrm{Cl}_{2}$ & 25 & 12 & $\mathbf{2 d}$ & 10 \\
6 & $\mathrm{AlBr}_{3} / \mathrm{CH}_{2} \mathrm{Cl}_{2}$ & 25 & 12 & $\mathbf{2 d}$ & 10 \\
7 & $\mathrm{AlBr}_{3} / \mathrm{PhNO}_{2}$ & 40 & 4 & $\mathbf{2 d}$ & 20 \\
\hline \multicolumn{7}{c}{ " represents that no desired product was obtained. }
\end{tabular}


Compound $2 \mathbf{e}$ showed weak activity at a maximum dissolvable dosage $(2.5 \mathrm{mg} / \mathrm{kg})$ in the mouse VF model (Figure 1B), thus, the 9-methoxy group in ring D might be one of the functional groups in aporphine alkaloids. Similarly, the 8- and/or 9- or 10-methoxylation in ring D of the aporphine skeleton, such as crebanine, stephanine, and L-isocrydine, showed notable antiarrhythmic activity. On the contrary, the removal of the 8- or 9- or 10-methyl groups of aporphine alkaloids in ring D may reduce antiarrhythmic activity.

\subsection{Racemization of Aporphines and Antiarrhythmic Activity}

Two racemic compounds of crebanine and stephanne, namely $( \pm)$ crebanine $(3 \mathbf{b})$ and $( \pm)$ stephanine (4b), were synthesized by reduction after dehydrogenation of $6 a-H$ (Scheme 3) [23]. Both compounds did not significantly manifest antiarrhythmic activity in the mouse model of VF induced by $\mathrm{CHCl}_{3}$ (Figure 1C). The results indicated that the levoduction of the 6a configuration was a functional group for maintaining antiarrhythmic activity.

\subsection{6a-H Dehydrogenated Derivatives of Aporphines and Antiarrhythmic Activity/Toxicity}

Dehydrocrebanine (3a) was derived from dehydrogenating in 6a-H of crebanine and the formation of a double bond in ring $\mathrm{C}$ of crebanine (Scheme 3). 3a showed a very high toxicity in animal tests. In order to avoid animal poisoning and death, the test dosage had to be decreased to $1 \mathrm{mg} / \mathrm{kg}$ (Figure 1C); however, antiarrhythmic activity was not obviously observed in the $\mathrm{CHCl}_{3}$-induced VF model either. On the other hand, stephanine and its derivative of $6 a-\mathrm{H}$ dehydrogenation (dehydrostephanine, $4 a)(5 \mathrm{mg} / \mathrm{kg})$, was able to notably confront $\mathrm{VF}$, caused by $\mathrm{CHCl}_{3}$, in mice (Figure 1C). In the rat model of arrhythmia induced by $\mathrm{BaCl}_{2}$, both stephanine and $4 \mathbf{a}$ increased the number of animals that resumed normal sinus rhythm $(p<0.01)$, and significantly shortened the time for recovery. However, 4 a was unable to maintain a sinus rhythm, even after more than 3 min post recovery (Table 1), and most of the tested animals died during the observation period $(20 \mathrm{~min})$, which implies that the effective duration of $\mathbf{4 a}$ was much shorter and the toxicity was high. These findings may be explained by the fact that dehydrogenation compounds increase the rigidity and conjugacy of the skeleton due to ring $\mathrm{C}$ forming a double bond $(\mathbf{3 a}, \mathbf{4 a})$, which facilitated the infusion of aporphine molecules infusing myocardial cells, and consequently producing much faster and stronger toxic effects relative to the prototype compounds.

\subsection{1-Alkylation and Quaternization of Isocorydine}

Figure 1D and Table 1 show that isocorydine $(10 \mathrm{mg} / \mathrm{kg})$ displayed lower antiarrhythmic activity tendencies compared to crebanine $(5 \mathrm{mg} / \mathrm{kg})$ and stephanine $(5 \mathrm{mg} / \mathrm{kg})$. The main difference in these three compounds lies on the 1,2-dimethoxy group of ring A, which exists in crebanine and stephanine, but not in isocorydine. This increase in antiarrhythmic activity may be related to the 1,2-dimethoxy group structure, which widens the planar configuration of molecules.

All of the modified products of isocorydine, $\mathbf{5 a}, \mathbf{5} \mathbf{b}, \mathbf{5} \mathbf{c}$, and $\mathbf{5} \mathbf{d}$ (Scheme 4) $[24,25]$ were inactive in the model of VF induced by $\mathrm{CHCl}_{3}$ (Figure 1D) at appropriate test dosages. Meanwhile, $\mathbf{5 a}$ and $\mathbf{5 d}$ were both $\mathrm{N}$-methylated as quaternary ammonium compounds, and presented such a high toxicity that the test dosages had to be reduced to $1 \mathrm{mg} / \mathrm{kg}$ (5a) and $0.8 \mathrm{mg} / \mathrm{kg}$ (5d) (Table 1) to avoid animal death. The reactions of toxicity appeared, much like those of $N$-methylcrebanine (2d), in the central nervous system and the motor nervous system. The experiments also evidenced that the substitution of the 11-methoxy group (5b) or 11-ethoxy group (5c) of isocorydine did not have any benefits for antiarrhythmic activity.

\subsection{Design of An Analogue of Crebanine}

An analogue of crebanine, compound $\mathbf{6 c}$, was designed and synthesized according to the key group of crebanine (Scheme 5), which contained two basic sites, a tertiary amine group and a dimethoxy-benzene group. However, animal tests showed that $\mathbf{6 c}$ could not significantly 
inhibit the occurrence of VF induced in mice. Therefore, it is necessary to design a series of dimethoxy-phenylamine derivatives in order to seek out the potential active compound.

\section{Experimental Section}

\subsection{Synthesis}

\subsubsection{General Information}

Isocorydine, crebanine, and stephanine were extracted from the plant, identified as Stephania yunnanensis Lo by Professor Yunshu Ma, Yunnan University of Traditional Chinese Medicine, and as reported previously [26,27]. Solvents and reagents used in syntheses were of analytical grade, were purchased from commercial sources, and used without further purification.

All reactions were carried out under an atmosphere of argon, with magnetic stirring, in flame dried or oven-dried glassware. Analytical thin layer chromatography was performed on $0.25-\mathrm{mm}$ silica gel GF 254 plates (Qingdao Haiyang Chemical Co., Ltd., Qingdao, China). Visualization was accomplished with UV light and bismuth potassium iodide solution staining followed by heating. 1H-NMR spectra were recorded on a $400 \mathrm{MHz}$ spectrometer (Amersham Pharmacia Biotech AB Inc., Tokyo, Japan) in $\mathrm{CDCl}_{3}$ or $\mathrm{CD}_{3} \mathrm{OD}$ at ambient temperature, using the solvent signal as an internal standard. Data are reported as: (br/broad, s/singlet, d/doublet, t/triplet, q/quartet, $\mathrm{m} /$ multiplet; integration; coupling constant(s) in hertz). ${ }^{13} \mathrm{C}-\mathrm{NMR}$ spectra were recorded on a $400 \mathrm{MHz}$ spectrometer (Amersham Pharmacia Biotech $\mathrm{AB}$ Inc., Tokyo, Japan) in $\mathrm{CDCl}_{3}$ at ambient temperature, using the solvent signal as an internal standard. Electrospray ionization mass spectrometry was detected with a Brukerama Zon SL (Bruker Daltonics Inc., Leipzig, Bremen, Germany); HR-MS was detected with 6200 series TOF/6500 series (Agilent Technologies Inc., Santa Clara, UT, USA); rotation was detected with a WZZ-three digital automatic polarimeter (Shanghai Shengguang Technology Co., Ltd., Shanghai, China).

\subsubsection{Preparation of Secocrebanine (1a)}

A mixture of crebanine $(2 \mathrm{~g}, 5.9 \mathrm{mmol})$ and $\mathrm{K}_{2} \mathrm{CO}_{3}(1.7 \mathrm{~g}, 1.2 \mathrm{mmol})$ in 1,2-dichloroethane $(20 \mathrm{~mL})$ was stirred and 1-chloroethyl chloroformate $(1.0 \mathrm{~g}, 7.1 \mathrm{mmol})$ was added slowly. The mixture was heated to $85^{\circ} \mathrm{C}$ for $6 \mathrm{~h}$, the 1,2-dichloroethane-insoluble material was filtered off, and the filtrate was concentrated to give the residue, which was dissolved in $\mathrm{MeOH}(20 \mathrm{~mL})$ and five drops of $37 \% \mathrm{HCl}$, and refluxed for $2 \mathrm{~h}$. The solution was concentrated and neutralized with saturated $\mathrm{Na}_{2} \mathrm{CO}_{3}$, and the residue was extracted with $\mathrm{CH}_{2} \mathrm{Cl}_{2}$. The combined extracts were dried over anhydrous $\mathrm{Na}_{2} \mathrm{SO}_{4}$, filtered, and concentrated to get a crude product, which was crystallized from EtOAC at $4{ }^{\circ} \mathrm{C}$, yielding compound $1 \mathrm{a}(1.2 \mathrm{~g}, 60 \%)$ as a pink-white solid. ${ }^{1} \mathrm{H}-\mathrm{NMR}\left(400 \mathrm{MH}_{\mathrm{Z}}, \mathrm{CDCl}_{3}, \delta ; \mathrm{ppm}\right) 8.83\left(\mathrm{~d}, J=9.2 \mathrm{H}_{\mathrm{Z}}\right.$ $1 \mathrm{H}, 5-\mathrm{H}), 7.93(\mathrm{~d}, J=9.6 \mathrm{HZ}, 1 \mathrm{H}, 10-\mathrm{H}), 7.87(\mathrm{~d}, J=9.6 \mathrm{HZ}, 1 \mathrm{H}, 9-\mathrm{H}), 7.29\left(\mathrm{~d}, J=8.8 \mathrm{H}_{\mathrm{Z}}, 1 \mathrm{H}, 6-\mathrm{H}\right), 7.10$ $(\mathrm{s}, 1 \mathrm{H}, 2-\mathrm{H}), 6.22\left(\mathrm{~s}, 2 \mathrm{H},-\mathrm{OCH}_{2} \mathrm{O}-\right), 4.02\left(\mathrm{~s}, 3 \mathrm{H}, 8-\mathrm{OCH}_{3}\right), 4.00\left(\mathrm{~s}, 3 \mathrm{H}, 9-\mathrm{OCH}_{3}\right), 3.28-3.24\left(\mathrm{t}, J=7.2 \mathrm{H}_{\mathrm{Z}}\right.$ $\left.2 \mathrm{H},-\mathrm{CH}_{2 \alpha}\right), 2.97-2.93\left(\mathrm{t}, J=7.2 \mathrm{H}_{\mathrm{Z}}, 2 \mathrm{H},-\mathrm{CH}_{2 \beta}\right), 2.47\left(\mathrm{~s}, 3 \mathrm{H},-\mathrm{NCH}_{3}\right) ;{ }^{13} \mathrm{C}-\mathrm{NMR}\left(100 \mathrm{MH}_{\mathrm{Z}}, \mathrm{CDCl}_{3}, \delta\right.$; ppm) $33.87\left(\mathrm{t},-\mathrm{CH}_{2 \beta}\right), 36.43\left(\mathrm{q}, \mathrm{N}-\mathrm{CH}_{3}\right), 53.12\left(\mathrm{t},-\mathrm{CH}_{2 \alpha}\right), 56.30\left(\mathrm{q}, 7-\mathrm{OCH}_{3}\right), 61.32\left(\mathrm{q}, 8-\mathrm{OCH}_{3}\right), 100.95$ $\left(\mathrm{t},-\mathrm{OCH}_{2} \mathrm{O}-\right), 110.05$ (d, C-2), 112.60 (d, C-6), 117.11 (s, C-8a), 118.38 (d, C-5), 123.26 (s, C-4a), 123.64 (d, C-9), 123.79 (d, C-10), 125.19 (s, C-1a), 127.41 (s, C-5a), 130.88 (s, C-1), 141.76 (s, C-4), 143.23 (s, C-7), 144,98 (s, C-3), 149.96 (s, C-8), Positive ESI-MS m/z: $340.2[\mathrm{M}+\mathrm{H}]^{+}$. HR-MS for $\mathrm{C}_{20} \mathrm{H}_{21} \mathrm{NO}_{4}[\mathrm{M}+\mathrm{H}]^{+}$; calcd. 340.1543 , found: 340.1542 .

\subsubsection{Preparation of $\mathrm{N}$-Cyclopropylmethylsecocrebanine (1b)}

Product 1a (200 mg, $0.59 \mathrm{mmol}), \mathrm{K}_{2} \mathrm{CO}_{3}(163 \mathrm{mg}, 1.18 \mathrm{mmol})$, and cyclopropylmethyl bromide $(96 \mathrm{mg}, 0.71 \mathrm{mmol})$ were added to $\mathrm{MeCN}(20 \mathrm{~mL})$ and heated at $80^{\circ} \mathrm{C}$ for $4 \mathrm{~h}$. The reaction mixture was filtered and concentrated to give a residue, which was purified by silica column chromatography $\left(\mathrm{CHCl}_{3} / \mathrm{MeOH}\right.$ 80:1), yielding compound $\mathbf{1 b}(180 \mathrm{mg}, 78 \%)$ as a white solid. ${ }^{1} \mathrm{H}-\mathrm{NMR}\left(400 \mathrm{MH}_{\mathrm{Z}}\right.$ 
$\left.\mathrm{CDCl}_{3}, \delta ; \mathrm{ppm}\right) 8.81\left(\mathrm{~d}, J=9.2 \mathrm{H}_{\mathrm{Z}}, 1 \mathrm{H}, 5-\mathrm{H}\right), 8.04\left(\mathrm{~d}, J=9.6 \mathrm{H}_{\mathrm{Z}}, 1 \mathrm{H}, 10-\mathrm{H}\right), 7.93\left(\mathrm{~d}, J=9.2 \mathrm{H}_{\mathrm{Z}}, 1 \mathrm{H}, 9-\mathrm{H}\right)$, $7.31\left(\mathrm{~d}, J=8.4 \mathrm{H}_{\mathrm{Z}}, 1 \mathrm{H}, 6-\mathrm{H}\right), 7.16(\mathrm{~s}, 1 \mathrm{H}, 2-\mathrm{H}), 6.23\left(\mathrm{~s}, 2 \mathrm{H},-\mathrm{OCH}_{2} \mathrm{O}-\right), 4.02\left(\mathrm{~s}, 3 \mathrm{H}, 8-\mathrm{OCH}_{3}\right), 3.99(\mathrm{~s}, 3 \mathrm{H}$, 9- $\left.\mathrm{OCH}_{3}\right), 3.84-3.78\left(\mathrm{~m}, 1 \mathrm{H}, \mathrm{CH}_{2 \alpha}\right), 3.66-3.60\left(\mathrm{~m}, 1 \mathrm{H},-\mathrm{CH}_{2 \beta}\right), 3.47-3.42\left(\mathrm{~m}, 1 \mathrm{H},-\mathrm{CH}_{2 \beta}\right), 3.18-3.15(\mathrm{~m}$, $\left.2 \mathrm{H}, \mathrm{N}-\mathrm{CH}_{2}\right), 2.97\left(\mathrm{~s}, 3 \mathrm{H},-\mathrm{NCH}_{3}\right), 2.93-2.89\left(\mathrm{~m}, 1 \mathrm{H}, \mathrm{CH}_{2 \alpha}\right), 1.30-1.25(\mathrm{~m}, 1 \mathrm{H},-\mathrm{CH}), 0.85-0.82(\mathrm{~m}, 2 \mathrm{H}$, $\left.-\mathrm{CH}_{2}\right), 0.50-0.47\left(\mathrm{~m}, 1 \mathrm{H},-\mathrm{CH}_{2}\right) .{ }^{13} \mathrm{C}-\mathrm{NMR}\left(100 \mathrm{MH}_{\mathrm{Z}}, \mathrm{CDCl}_{3}, \delta ; \mathrm{ppm}\right) 100.62\left(\mathrm{t},-\mathrm{OCH}_{2} \mathrm{O}-\right), 52.82(\mathrm{t}$, $\left.-\mathrm{CH}_{2 \beta}\right), 29.59\left(\mathrm{t}, \mathrm{CH}_{2 \alpha}\right), 29.26\left(\mathrm{t},-\mathrm{CH}_{2}\right), 29.05\left(\mathrm{t},-\mathrm{CH}_{2}\right), 61.00\left(\mathrm{q}, 8-\mathrm{OCH}_{3}\right), 56.02\left(\mathrm{q}, 8-\mathrm{OCH}_{3}\right), 43.97(\mathrm{q}$, $\left.\mathrm{N}-\mathrm{CH}_{3}\right), 115.77$ (d, C-5), 114.88 (d, C-6),62.40(d, -CH), 152.55 (s, C-8), 145.17 (s, C-3), 145.02 (s, C-7), 141.99 (s, C-4), 133.19 (s, C-1),130.69 (s, C-5a), 125.73(s, C-1a), 124.66 (s, C-4a), 114.88(s, C-8a). Positive ESI-MS m/z: $394.2[\mathrm{M}+\mathrm{H}]^{+}$. HR-MS for $\mathrm{C}_{24} \mathrm{H}_{27} \mathrm{NO}_{4}[\mathrm{M}+\mathrm{H}]^{+}$; calcd. 394.2013, found: 394.2026.

\subsubsection{Preparation of $N$-Trifluoroacetamidesecocrebanine (1c)}

A solution of $1 \mathrm{a}(200 \mathrm{mg}, 0.59 \mathrm{mmol})$ and $\mathrm{Et}_{3} \mathrm{~N}(72 \mathrm{mg}, 0.71 \mathrm{mmol})$ in anhydrous $\mathrm{CH}_{2} \mathrm{Cl}_{2}$ (30 mL), trifluoroacetic anhydride $(149 \mathrm{mg}, 0.71 \mathrm{mmol})$ was slowly added under an ice-bath, then, the solution was stirred for $2 \mathrm{~h}$ at room temperature. The mixture was diluted with water $(20 \mathrm{~mL})$ and extracted with $\mathrm{CH}_{2} \mathrm{Cl}_{2}(3 \times 10 \mathrm{~mL})$. The combined extracts were dried over anhydrous $\mathrm{Na}_{2} \mathrm{SO}_{4}$, filtered and concentrated to give a crude product, which was purified by silica gel column chromatography $\left(\mathrm{CH}_{2} \mathrm{Cl}_{2} / \mathrm{MeOH} 100: 1\right)$, and yielding compound $1 \mathrm{c}(210 \mathrm{mg}, 82 \%)$ as a white solid. ${ }^{1} \mathrm{H}-\mathrm{NMR}\left(400 \mathrm{MH}_{\mathrm{Z}}\right.$ $\left.\mathrm{CDCl}_{3}, \delta ; \mathrm{ppm}\right) 8.83\left(\mathrm{~d}, J=9.2 \mathrm{H}_{\mathrm{Z}}, 1 \mathrm{H}, 5-\mathrm{H}\right), 7.99\left(\mathrm{~d}, J=9.2 \mathrm{H}_{\mathrm{Z}}, 1 \mathrm{H}, 10-\mathrm{H}\right), 7.94\left(\mathrm{~d}, J=9.6 \mathrm{H}_{\mathrm{Z}}, 1 \mathrm{H}, 9-\mathrm{H}\right)$, $7.31\left(\mathrm{~d}, J=9.2 \mathrm{H}_{\mathrm{Z}}, 1 \mathrm{H}, 6-\mathrm{H}\right), 7.07(\mathrm{~s}, 1 \mathrm{H}, 2-\mathrm{H}), 6.24\left(\mathrm{~s}, 1 \mathrm{H},-\mathrm{OCH}_{2} \mathrm{O}-\right), 6.23\left(\mathrm{~s}, 1 \mathrm{H},-\mathrm{OCH}_{2} \mathrm{O}-\right), 4.03(\mathrm{~s}$, $\left.3 \mathrm{H}, 8-\mathrm{OCH}_{3}\right), 4.00\left(\mathrm{~s}, 3 \mathrm{H}, 9-\mathrm{OCH}_{3}\right), 3.73-3.69\left(\mathrm{t}, J=7.4 \mathrm{H}_{\mathrm{Z}}, 2 \mathrm{H},-\mathrm{CH}_{2 \alpha}\right), 3.36-3.32\left(\mathrm{t}, J=7.2 \mathrm{H}_{\mathrm{Z}}, 2 \mathrm{H}\right.$, $\left.-\mathrm{CH}_{2 \beta}\right), 3.11\left(\mathrm{~s}, 1 \mathrm{H},-\mathrm{NCH}_{3}\right), 2.99\left(\mathrm{~s}, 2 \mathrm{H},-\mathrm{NCH}_{3}\right) .{ }^{13} \mathrm{C}-\mathrm{NMR}\left(100 \mathrm{MH}_{\mathrm{Z}}, \mathrm{CDCl}_{3}, \delta ; \mathrm{ppm}\right) 30.67\left(\mathrm{t}, \mathrm{CH}_{2 \alpha}\right)$, $36.04\left(\mathrm{q}, \mathrm{N}-\mathrm{CH}_{3}\right), 51.79\left(\mathrm{t},-\mathrm{CH}_{2 \beta}\right), 56.32\left(\mathrm{q}, 7-\mathrm{OCH}_{3}\right), 61.33\left(\mathrm{q}, 8-\mathrm{OCH}_{3}\right), 101.21\left(\mathrm{t},-\mathrm{OCH}_{2} \mathrm{O}-\right), 110.13(\mathrm{~d}$, C-2), 112.91 (d, C-6), 117.15 (s, C-8a), 119.12 (s, C-4a), 119.28 (d, C-5), 122.08 (s, CF $), 123.77$ (d, C-9), 123.81 (d, C-10), 125.39 (C-1a), 127.47 (C-5a), 128.83 (s, C-1), 142.27 (s, C-4), 143.32 (s, C-7), 145.08 (s, C-3), 150.15 (s, C-8). Positive ESI-MS m/z: $458.2[\mathrm{M}+\mathrm{Na}]^{+}$. HR-MS for $\mathrm{C}_{22} \mathrm{H}_{20} \mathrm{~F}_{3} \mathrm{NO}_{5}[\mathrm{M}+\mathrm{Na}]^{+}$; calcd. 458.1186, found: 458.1188 .

\subsubsection{Preparation of $N$-Acetamidesecocrebanine (1d)}

To a stirred solution of $1 \mathrm{a}$ ( $200 \mathrm{mg}, 0.59 \mathrm{mmol})$, 4-dimethylaminopyridine (144 mg, $1.18 \mathrm{mmol})$, and $\mathrm{Et}_{3} \mathrm{~N}(72 \mathrm{mg}, 0.71 \mathrm{mmol})$ in anhydrous $\mathrm{CH}_{2} \mathrm{Cl}_{2}(20 \mathrm{~mL})$, acetic anhydride $(72 \mathrm{mg}, 0.71 \mathrm{mmol})$ was slowly added and stirred for $4 \mathrm{~h}$ at room temperature. The mixture was diluted with water $(10 \mathrm{~mL})$ and extracted with $\mathrm{CH}_{2} \mathrm{Cl}_{2}(3 \times 10 \mathrm{~mL})$. The combined extracts were dried over anhydrous $\mathrm{Na}_{2} \mathrm{SO}_{4}$, filtered, and concentrated to get a crude product, which was purified by silica gel column chromatography $\left(\mathrm{CH}_{2} \mathrm{Cl}_{2} / \mathrm{MeOH} 100: 1\right)$, yielding compound $1 \mathrm{~d}(180 \mathrm{mg}, 80 \%)$ as a white solid. ${ }^{1} \mathrm{H}-\mathrm{NMR}\left(400 \mathrm{MH}_{\mathrm{Z}}\right.$, $\mathrm{CDCl}_{3}, \delta$; ppm) $8.83\left(\mathrm{~d}, J=8.4 \mathrm{H}_{\mathrm{Z}}, 1 \mathrm{H}, 5-\mathrm{H}\right), 8.00\left(\mathrm{~d}, J=10.0 \mathrm{H}_{\mathrm{Z}}, 1 \mathrm{H}, 10-\mathrm{H}\right) 7.96\left(\mathrm{~d}, J=9.6 \mathrm{H}_{\mathrm{Z}}, 1 \mathrm{H}\right.$, 9-H), $7.32\left(\mathrm{~d}, J=9.2 \mathrm{H}_{\mathrm{Z}}, 1 \mathrm{H}, 6-\mathrm{H}\right), 7.09(\mathrm{~s}, 1 \mathrm{H}, 2-\mathrm{H}), 6.23\left(\mathrm{~s}, 1 \mathrm{H},-\mathrm{OCH}_{2} \mathrm{O}-\right), 6.22\left(\mathrm{~s}, 1 \mathrm{H},-\mathrm{OCH}_{2} \mathrm{O}-\right), 4.03$ $\left(\mathrm{s}, 6 \mathrm{H}, 8-\mathrm{OCH}_{3}\right), 4.00\left(\mathrm{~s}, 6 \mathrm{H}, 9-\mathrm{OCH}_{3}\right), 3.67-3.61\left(\mathrm{dd}, J=15.6 \mathrm{H}_{\mathrm{Z}}, J=8.0 \mathrm{H}_{\mathrm{Z}}, 2 \mathrm{H},-\mathrm{CH}_{2 \alpha}\right), 3.31-3.27$ $\left(\mathrm{t}, J=7.4 \mathrm{H}_{\mathrm{Z}}, 2 \mathrm{H},-\mathrm{CH}_{2 \beta}\right), 3.00\left(\mathrm{~s}, 1 \mathrm{H},-\mathrm{NCH}_{3}\right), 2.81\left(\mathrm{~s}, 2 \mathrm{H},-\mathrm{NCH}_{3}\right), 2.09$ (s, $\left.2 \mathrm{H},-\mathrm{NOCH}_{3}\right), 1.85$ (s, $\left.1 \mathrm{H},-\mathrm{NOCH}_{3}\right) .{ }^{13} \mathrm{C}-\mathrm{NMR}\left(100 \mathrm{MH}_{\mathrm{Z}}, \mathrm{CDCl}_{3}, \delta ; \mathrm{ppm}\right) 22.03\left(\mathrm{q},-\mathrm{NOCH}_{3}\right), 32.57\left(\mathrm{t},-\mathrm{CH}_{2 \alpha}\right), 37.39(\mathrm{q}$, $\left.\mathrm{N}-\mathrm{CH}_{3}\right), 51.99\left(\mathrm{t},-\mathrm{CH}_{2 \beta}\right), 56.33\left(\mathrm{q}, 7-\mathrm{OCH}_{3}\right), 61.32\left(\mathrm{q}, 8-\mathrm{OCH}_{3}\right), 100.08\left(\mathrm{t},-\mathrm{OCH}_{2} \mathrm{O}-\right), 110.28(\mathrm{~d}, \mathrm{C}-2)$, 112.88 (d, C-6), 117.17 (s, C-8a), 119.10 (d, C-5),123.76 (d, C-9), 123.81 (d, C-10), 125.55 (s, C-4a), 127.50 (C-1a), 128.72 (C-5a), 130.31 (s, C-1), 142.30 (s, C-4), 143.28 (s, C-7), 145.14 (s, C-3), 150.11 (s, C-8), 170.69 (s, -C=O).Positive ESI-MS $m / z: 404.2[\mathrm{M}+\mathrm{Na}]^{+}$.HR-MS for $\mathrm{C}_{22} \mathrm{H}_{23} \mathrm{NO}_{5}[\mathrm{M}+\mathrm{Na}]^{+}$; calcd. 404.1468, found: 404.1474 .

\subsubsection{Preparation of N-Methylsulfonamidesecocrebanine (1e)}

To a mixture of $1 \mathrm{a}(200 \mathrm{mg}, 0.59 \mathrm{mmol})$ and $\mathrm{Et}_{3} \mathrm{~N}(72 \mathrm{mg}, 0.71 \mathrm{mmol})$ in anhydrous $\mathrm{CH}_{2} \mathrm{Cl}_{2}$ $(30 \mathrm{~mL})$ under an ice-bath, methanesulfonyl chloride $(81 \mathrm{mg}, 0.71 \mathrm{mmol})$ was slowly added and stirred for $2 \mathrm{~h}$ at room temperature. The mixture was diluted with water $(20 \mathrm{~mL})$ and extracted with $\mathrm{CH}_{2} \mathrm{Cl}_{2}$ $(3 \times 10 \mathrm{~mL})$. The combined extracts were dried over anhydrous $\mathrm{Na}_{2} \mathrm{SO}_{4}$, filtered, and concentrated to 
give a crude product, which was purified by silica gel column chromatography $\left(\mathrm{CH}_{2} \mathrm{Cl}_{2} / \mathrm{MeOH} 100: 1\right)$, yielding 1e (210 mg, 82\%) as a white solid. ${ }^{1} \mathrm{H}-\mathrm{NMR}\left(400 \mathrm{MH}_{\mathrm{Z}}, \mathrm{CDCl}_{3}, \delta ; \mathrm{ppm}\right) 8.83\left(\mathrm{~d}, J=9.2 \mathrm{H}_{\mathrm{Z}}\right.$, $1 \mathrm{H}, 5-\mathrm{H}), 7.98(\mathrm{~d}, J=9.6 \mathrm{HZ}, 1 \mathrm{H}, 10-\mathrm{H}), 7.85(\mathrm{~d}, J=9.6 \mathrm{HZ}, 1 \mathrm{H}, 9-\mathrm{H}), 7.31\left(\mathrm{~d}, J=9.2 \mathrm{H}_{\mathrm{Z}}, 1 \mathrm{H}, 6-\mathrm{H}\right)$, $7.11(\mathrm{~s}, 1 \mathrm{H}, 2-\mathrm{H}), 6.23\left(\mathrm{~s}, 2 \mathrm{H},-\mathrm{OCH}_{2} \mathrm{O}-\right), 4.03\left(\mathrm{~s}, 3 \mathrm{H}, 8-\mathrm{OCH}_{3}\right), 4.00\left(\mathrm{~s}, 3 \mathrm{H}, 9-\mathrm{OCH}_{3}\right), 3.46-3.42(\mathrm{~m}, 2 \mathrm{H}$, $\left.-\mathrm{CH}_{2 \alpha}\right), 3.37-3.34\left(\mathrm{~m}, 2 \mathrm{H},-\mathrm{CH}_{2 \beta}\right), 2.92\left(\mathrm{~s}, 3 \mathrm{H},-\mathrm{NCH}_{3}\right), 2.74\left(\mathrm{~s}, 3 \mathrm{H},-\mathrm{NSO}_{2} \mathrm{CH}_{3}\right) .{ }^{13} \mathrm{C}-\mathrm{NMR}\left(100 \mathrm{MH}_{\mathrm{Z}}\right.$ $\left.\mathrm{CDCl}_{3}, \delta ; \mathrm{ppm}\right) 33.26\left(\mathrm{t},-\mathrm{CH}_{2 \alpha}\right), 35.38\left(\mathrm{t},-\mathrm{NSO}_{2} \mathrm{CH}_{3}\right), 51.56\left(\mathrm{t},-\mathrm{CH}_{2 \beta}\right), 56.31\left(\mathrm{q}, 7-\mathrm{OCH}_{3}\right), 61.34(\mathrm{q}$, 8- $\left.\mathrm{OCH}_{3}\right), 101.10\left(\mathrm{t},-\mathrm{OCH}_{2} \mathrm{O}-\right), 110.30(\mathrm{~d}, \mathrm{C}-2), 112.76(\mathrm{~d}, \mathrm{C}-6), 117.13$ (s, C-8a), 119.06 (d, C-5), 122.72 (d, C-9),123.77 (d, C-10),125.21 (s, C-4a),127.40 (C-1a), 128.88 (s, C-1), 142.20 (s, C-4),143.29 (s, C-7), 145.07 (s, C-3),150.07 (s, C-8). Positive ESI-MS m/z: 440.2 [M + Na] $]^{+}$. HR-MS for $\mathrm{C}_{21} \mathrm{H}_{23} \mathrm{NO}_{6} \mathrm{~S}[\mathrm{M}+\mathrm{Na}]^{+}$; calcd. 440.1138 , found: 440.1140 .

3.1.7. Preparation of 3,10,11-Tribromocrebanine (2a), 10,11-Dibromocrebanine (2b) and 3-Bromocrebanine (2c)

Crebanine (200 mg, $0.59 \mathrm{mmol})$ and N-Bromosuccinimide $(213.6 \mathrm{mg}, 1.2 \mathrm{mmol})$ were added to trifluoroacetic acid $(5 \mathrm{~mL})$, the mixture was stirred for 18 hat room temperature, diluted with water $(10 \mathrm{~mL})$, and neutralized with saturated $\mathrm{NaHCO}_{3}$ and extracted with $\mathrm{CH}_{2} \mathrm{Cl}_{2}(3 \times 10 \mathrm{~mL})$. The combined $\mathrm{CH}_{2} \mathrm{Cl}_{2}$ solution was brined with water, dried over anhydrous $\mathrm{Na}_{2} \mathrm{SO}_{4}$, filtered, and concentrated to give a crude product, which was purified by silica gel column chromatography $\left(\mathrm{CH}_{2} \mathrm{Cl}_{2} / \mathrm{MeOH} 200: 1 \rightarrow 100: 1\right)$, yielding compound $2 \mathrm{a}$ (52 mg, 27\%), compound $2 \mathbf{b}$ (50 mg, 17\%), and compound $2 \mathrm{c}(80 \mathrm{mg}, 33 \%)$.

Compound 2a, pale yellow solid. ${ }^{1} \mathrm{H}-\mathrm{NMR}\left(400 \mathrm{MH}_{\mathrm{Z}}, \mathrm{CDCl}_{3}, \delta ; \mathrm{ppm}\right) 6.16\left(1 \mathrm{H}, \mathrm{s}, 9,-\mathrm{OCH}_{2} \mathrm{O}-\right)$, $6.06\left(1 \mathrm{H}, \mathrm{s},-\mathrm{OCH}_{2} \mathrm{O}-\right), 3.93\left(3 \mathrm{H}, \mathrm{s}, 8-\mathrm{OCH}_{3}\right), 3.87\left(3 \mathrm{H}, \mathrm{s}, 9-\mathrm{OCH}_{3}\right), 3.54\left(1 \mathrm{H}, \mathrm{d}, J=12.8 \mathrm{H}_{\mathrm{Z}}, 6 \mathrm{a}-\mathrm{H}\right)$, 3.16-3.09 (m, 1H, 7-Ha), 2.99-2.91 (m, 2H, 5-Ha, 7-Hb), 2.77-2.72 (m, 1H, 5-Ha), 2.60 (s, 3H, - $\left.\mathrm{NCH}_{3}\right)$, 2.53-2.50 (m, 1H, 4-Ha), 2.15-2.02 (m, 1H, 4-Hb). ${ }^{13} \mathrm{C}-\mathrm{NMR}\left(100 \mathrm{MH}_{\mathrm{Z}}, \mathrm{CDCl}_{3}, \delta ; \mathrm{ppm}\right), 29.29(\mathrm{t}, \mathrm{C}-7)$, $29.33(\mathrm{t}, \mathrm{C}-4), 52.78(\mathrm{t}, \mathrm{C}-5), 44.02\left(\mathrm{t},-\mathrm{NCH}_{3}\right), 60.82\left(\mathrm{q}, 9-\mathrm{OCH}_{3}\right), 61.17\left(\mathrm{q}, 8-\mathrm{OCH}_{3}\right), 62.18(\mathrm{~d}, \mathrm{C}-6 \mathrm{a})$, $100.77\left(\mathrm{t},-\mathrm{OCH}_{2} \mathrm{O}-\right), 102.96$ (s, C-3), 115.29 (s, C-10), 118.63 (s, C-11), 125.78 (s, C-7a), 129.83 (s, C-1b), 130.73 (s, C-3a), 132.67 (s, C-11a), 142.26 (s, C-1), 145.28 (s, C-8), 149.72 (s, C-2), 150.88 (s, C-9a). Positive ESI-MS m/z: $579.2[\mathrm{M}+3]^{+}$. HR-MS for $\mathrm{C}_{20} \mathrm{H}_{18} \mathrm{Br}_{3} \mathrm{NO}_{4}[\mathrm{M}+\mathrm{H}]^{+}$; calcd.573.8859, found:573.8853.

Compound 2b, white solid. ${ }^{1} \mathrm{H}-\mathrm{NMR}\left(400 \mathrm{MH}_{\mathrm{Z}}, \mathrm{CDCl}_{3}, \delta\right.$; ppm) $7.13(\mathrm{~s}, 1 \mathrm{H}, 3-\mathrm{H}), 6.14(\mathrm{~s}, 1 \mathrm{H}$, $\left.-\mathrm{OCH}_{2} \mathrm{O}-\right), 6.05\left(\mathrm{~s}, 1 \mathrm{H},-\mathrm{OCH}_{2} \mathrm{O}-\right), 3.89\left(\mathrm{~s}, 3 \mathrm{H}, 8-\mathrm{OCH}_{3}\right), 3.79\left(\mathrm{~s}, 3 \mathrm{H}, 9-\mathrm{OCH}_{3}\right), 3.61-3.57(\mathrm{~m}, 1 \mathrm{H}, 6 \mathrm{a}-\mathrm{H})$, 3.11-3.07 (m, 1H, 7-Ha), 2.97-2.87 (m, 2H, 5-Ha, 7-Hb), 2.80-2.66 (m, 1H, 5- $\mathrm{Hb}), 2.56\left(\mathrm{~s}, 3 \mathrm{H},-\mathrm{NCH}_{3}\right)$, 2.52-2.47 (m, 1H, 4-Ha), 2.11-2.04 (t, $J=13.6 \mathrm{~Hz}, 1 \mathrm{H}, 4-\mathrm{Hb}) .{ }^{13} \mathrm{C}-\mathrm{NMR}\left(100 \mathrm{MH}_{\mathrm{Z}}, \mathrm{CDCl}_{3}, \delta\right.$; ppm) $100.62\left(\mathrm{t},-\mathrm{OCH}_{2} \mathrm{O}-\right), 52.82$ (t, C-5), 29.26 (t, C-4), 29.05 (t, C-7), 62.40 (d, C-6a), 115.95 (d, C-3), 152,55 (s, C-9), 145.17 (s, C-2), 145.09 (s, C-8), 141.99 (s, C-1), 133.19 (s, C-11a), 130.69 (s, C-3a), 125.73 (s, C-7a), 124.66 (s, C-1a). Positive ESI-MS m/z: $498.0[\mathrm{M}+\mathrm{H}]^{+}$. HR-MS for $\mathrm{C}_{20} \mathrm{H}_{19} \mathrm{Br}_{2} \mathrm{NO}_{4}[\mathrm{M}+\mathrm{H}]^{+}$; calcd. 495.9754, found: 495.9759 .

Compound 2c, white solid. Positive ESI-MS $m / z: 418[\mathrm{M}]^{+}, 420.0[\mathrm{M}+2]^{+} .{ }^{1} \mathrm{H}-\mathrm{NMR}\left(400 \mathrm{MH}_{\mathrm{Z}}\right.$, $\left.\mathrm{CDCl}_{3}, \delta ; \mathrm{ppm}\right) 7.76\left(\mathrm{~d}, J=8.8 \mathrm{H}_{\mathrm{Z}}, 1 \mathrm{H}, 11-\mathrm{H}\right), 6.90\left(\mathrm{~d}, J=8.8 \mathrm{H}_{\mathrm{Z}}, 1 \mathrm{H}, 10-\mathrm{H}\right), 6.22\left(\mathrm{~s}, 1 \mathrm{H},-\mathrm{OCH}_{2} \mathrm{O}-\right)$, $6.07\left(\mathrm{~s}, 1 \mathrm{H},-\mathrm{OCH}_{2} \mathrm{O}-\right), 3.91\left(\mathrm{~s}, 3 \mathrm{H}, 8-\mathrm{OCH}_{3}\right), 3.84\left(\mathrm{~s}, 3 \mathrm{H}, 9-\mathrm{OCH}_{3}\right), 3.82-3.80(\mathrm{~m}, 1 \mathrm{H}, 6 \mathrm{a}-\mathrm{H}), 3.09-3.04(\mathrm{~m}$, $2 \mathrm{H}, 5-\mathrm{Ha}, 7-\mathrm{Hb}), 2.90-2.82(\mathrm{~m}, 2 \mathrm{H}, 5-\mathrm{Ha}, 7-\mathrm{Hb}), 2.17$ (s, 3H, $\left.-\mathrm{NCH}_{3}\right), 1.95-1.87$ (m, 1H, 4-Ha), 1.79-1.72 $(\mathrm{m}, 1 \mathrm{H}, 4-\mathrm{Hb})$.

\subsubsection{Preparation of N-Methylcrebanine (2d)}

A mixture of crebanine (200 mg, $0.59 \mathrm{mmol})$, ether $(109 \mathrm{mg}, 1.48 \mathrm{mmol})$ and $\mathrm{CH}_{3} \mathrm{I}(184.5 \mathrm{mg}$, $1.3 \mathrm{mmol})$ in $\mathrm{MeOH}(10 \mathrm{~mL})$ was stirred for $16 \mathrm{~h}$ at room temperature. The reaction mixture was concentrated and extracted with $\mathrm{CHCl}_{3}(3 \times 10 \mathrm{~mL})$. The combined extracts were dried over anhydrous $\mathrm{Na}_{2} \mathrm{SO}_{4}$, filtered, and concentrated to give a crude product, which was purified by silica gel column chromatography $\left(\mathrm{CH}_{2} \mathrm{Cl}_{2} / \mathrm{MeOH} 30: 1\right)$, yielding compound $2 \mathrm{~d}(180 \mathrm{mg}, 86 \%)$ as a white solid. ${ }^{1} \mathrm{H}-\mathrm{NMR}\left(400 \mathrm{MH}_{\mathrm{Z}}, \mathrm{CDCl}_{3}, \delta\right.$; ppm) $7.70(\mathrm{~d}, J=8.8 \mathrm{~Hz}, 1 \mathrm{H}, 11-\mathrm{H}), 7.05(\mathrm{~d}, J=8.8 \mathrm{~Hz}, 1 \mathrm{H}, 10-\mathrm{H})$, $6.78(\mathrm{~s}, 1 \mathrm{H}, 3-\mathrm{H}), 6.18$ (s, 1H, - $\left.-\mathrm{OCH}_{2} \mathrm{O}-\right), 5.98$ (s, 1H, - $\left.\mathrm{OCH}_{2} \mathrm{O}-\right), 4.74-4.70(\mathrm{~m}, 1 \mathrm{H}, 6 \mathrm{a}-\mathrm{H}), 3.80(\mathrm{~s}, 3 \mathrm{H}$, 
8- $\mathrm{OCH}_{3}$ ), 3.76-3.73 (m, 1H, 7-Ha), $3.72\left(\mathrm{~s}, 3 \mathrm{H}, 9-\mathrm{OCH}_{3}\right), 3.64-3.55$ (m, 2H, 7-Hb,5-Ha), 3.33 (s, 3H, $\left.-\mathrm{NCH}_{3}\right), 3.18-3.09(\mathrm{~m}, 1 \mathrm{H}, 5-\mathrm{Hb}), 2.97\left(\mathrm{~s}, 3 \mathrm{H},-\mathrm{NCH}_{3}\right), 2.94-2.89(\mathrm{~m}, 1 \mathrm{H}, 4-\mathrm{Ha}), 2.70-2.63(\mathrm{t}, J=14.2 \mathrm{~Hz}$, $1 \mathrm{H}, 4 \mathrm{Hb})$. Positive ESI-MS m/z: $354.2[\mathrm{M}]^{+}$.

\subsubsection{Preparation of Stesakine (2e)}

Crebanine (200 mg, $0.59 \mathrm{mmol}$ ) in $2 \mathrm{~mL}$ of anhydrous $\mathrm{CH}_{2} \mathrm{Cl}_{2}$ was slowly added into a suspension of $\mathrm{AlBr}_{3}(320 \mathrm{mg}, 1.2 \mathrm{mmol})$ in nitrobenzene $(5 \mathrm{~mL})$ at $5{ }^{\circ} \mathrm{C}$ under argon. The solution was stirred for $18 \mathrm{~h}$, diluted with water $(20 \mathrm{~mL})$ and neutralized with saturated $\mathrm{NaHCO}_{3}$. The mixture was extracted with $\mathrm{CH}_{2} \mathrm{Cl}_{2}(3 \times 10 \mathrm{~mL})$, and the combined $\mathrm{CH}_{2} \mathrm{Cl}_{2}$ solution was brined with water, dried with anhydrous $\mathrm{Na}_{2} \mathrm{SO}_{4}$, filtered, and concentrated to give a crude product, which was purified by silica gel column chromatography $\left(\mathrm{CH}_{2} \mathrm{Cl}_{2} / \mathrm{MeOH}\right.$ 50:1), yieldingcompound $2 \mathrm{e}(56 \mathrm{mg}, 29 \%)$ as a colorless oil. ${ }^{1} \mathrm{H}-\mathrm{NMR}\left(400 \mathrm{MH}_{\mathrm{Z}}, \mathrm{CDCl}_{3}, \delta\right.$; ppm) $7.63\left(\mathrm{~d}, J=8.8 \mathrm{H}_{\mathrm{Z}}, 1 \mathrm{H}, 11-\mathrm{H}\right), 6.83\left(\mathrm{~d}, J=8.8 \mathrm{H}_{\mathrm{Z}}, 1 \mathrm{H}, 10-\mathrm{H}\right)$, 6.53 (s, 1H, 3-H), 6.06 (s, 1H, - $\left.\mathrm{OCH}_{2} \mathrm{O}-\right)$, 5.92 (s, 1H, - $\left.\mathrm{OCH}_{2} \mathrm{O}-\right)$, 5.77 (s, 1H, 9-OH), $3.93\left(\mathrm{~s}, 3 \mathrm{H}, 8-\mathrm{CH}_{3}\right)$, 3.69-3.64 (dd, $\left.J=16.0 \mathrm{H}_{\mathrm{Z}}, J=4.0 \mathrm{H}_{\mathrm{Z}}, 1 \mathrm{H}, 6 \mathrm{a}-\mathrm{H}\right), 3.19-3.03(\mathrm{~m}, 3 \mathrm{H}, 7-\mathrm{H}, 5-\mathrm{Ha}), 2.65-2.61(\mathrm{~m}, 1 \mathrm{H}, 5-\mathrm{Hb})$, $2.60\left(\mathrm{~s}, 3 \mathrm{H},-\mathrm{NCH}_{3}\right), 2.56-2.50(\mathrm{~m}, 1 \mathrm{H}, 4-\mathrm{Ha}), 2.32-2.25\left(\mathrm{t}, J=10.4 \mathrm{H}_{\mathrm{Z}}, 1 \mathrm{H}, 4-\mathrm{Hb}\right),{ }^{13} \mathrm{C}-\mathrm{NMR}\left(100 \mathrm{MH}_{\mathrm{Z}}\right.$, $\mathrm{CDCl}_{3}, \delta$; ppm) 142.2 (s, C-1), 116.7 (s, C-1a), 126.5 (s, C-1b), 146.6 (s, C-2), 106.7 (d, C-3), 126.7 (s, C-3a), $26.3(\mathrm{t}, \mathrm{C}-4), 56$ (t, C-5), 61.9 (d, 6a), 29.2 (t, C-7), 124.8 (s, C-7a), 156.4 (s, C-8), 145.8 (s, C-9), 108.5 (d, t-10), 118.7 (d, C-11), 126.6 (s, C-11a), 100.1 (t, $\left.-\mathrm{CH}_{2} \mathrm{O}-\right), 44.0$ (q, $\left.-\mathrm{NCH}_{3}\right), 56.0$ (q, 8-OCH $)_{3}$. Positive ESI-MS $m / z: 326[\mathrm{M}+\mathrm{H}]^{+}$.

\subsubsection{Preparation of Dehydrocrebanine (3a)}

$\mathrm{Pd} / \mathrm{C}(10 \%, 210 \mathrm{mg})$ was added to a suspension of crebanine $(200 \mathrm{mg}, 0.59 \mathrm{mmol})$ in $\mathrm{MeCN}$ $(20 \mathrm{~mL})$, and the solution was refluxed for $6 \mathrm{~h}$ under $\mathrm{N}_{2}$. The mixture reaction solution was filtered and the filtrate was evaporated to give compound $3 \mathrm{a}(181 \mathrm{mg}, 91 \%)$ as a yellowish-green solid. ${ }^{1} \mathrm{H}-\mathrm{NMR}$ $\left(400 \mathrm{MH}_{\mathrm{Z}}, \mathrm{CDCl}_{3}, \delta\right.$; ppm) $8.66(\mathrm{~d}, J=8.8 \mathrm{~Hz}, 1 \mathrm{H}, 11-\mathrm{H}), 7.03(\mathrm{~d}, J=9.2 \mathrm{~Hz}, 1 \mathrm{H}, 10-\mathrm{H}), 6.89(\mathrm{~s}, 2 \mathrm{H}, 3-\mathrm{H}$, 7-H), 6.19 (s, 2H, $\left.-\mathrm{OCH}_{2} \mathrm{O}-\right), 3.99\left(\mathrm{~s}, 3 \mathrm{H}, 8-\mathrm{OCH}_{3}\right), 3.97\left(\mathrm{~s}, 3 \mathrm{H}, 9-\mathrm{OCH}_{3}\right), 3.34-3.37(\mathrm{t}, J=5.8 \mathrm{~Hz}, 2 \mathrm{H}$, 5-H), 3.24-3.31 (t, J = 5.8 Hz, 2H, 4-H), $3.13\left(\mathrm{~s}, 3 \mathrm{H},-\mathrm{NCH}_{3}\right)$. Positive ESI-MS m/z: $348.2[\mathrm{M}+\mathrm{H}]^{+}$.

\subsubsection{Preparation of $( \pm)$ Crebanine (3b)}

A mixture of $3 a(150 \mathrm{mg}, 0.44 \mathrm{mmol})$ and $\mathrm{NaCNBH}_{3}(36 \mathrm{mg}, 0.57 \mathrm{mmol})$ in absolute EtOH was stirred, and a mixture of EtOH and $2 \mathrm{NHCl}$ was added until the pH approached 3.0 (within $4 \mathrm{~h}$ ). Then, the solution was continuously stirred for $18 \mathrm{~h}$ at room temperature. After evaporation of the reaction mixture, the $\mathrm{pH}$ was adjusted to 8 with saturated $\mathrm{Na}_{2} \mathrm{CO}_{3}$ and the mixture solution was extracted with $\mathrm{CH}_{2} \mathrm{Cl}_{2}(3 \times 10 \mathrm{~mL})$. The combined extracts were dried over anhydrous $\mathrm{Na}_{2} \mathrm{SO}_{4}$, filtered, and concentrated to get a crude product, which was purified by silica gel column chromatography $\left(\mathrm{CH}_{2} \mathrm{Cl}_{2} / \mathrm{MeOH} 50: 1\right)$, yielding compound $3 \mathbf{b}(120 \mathrm{mg}, 80 \%)$ as a yellow oil. $[\alpha]_{D}^{25}: 0^{\circ}(\mathrm{C} 0.2, \mathrm{MeOH})$. ${ }^{1} \mathrm{H}-\mathrm{NMR}\left(400 \mathrm{MH}_{\mathrm{Z}}, \mathrm{CDCl}_{3}, \delta\right.$; ppm) $7.81(\mathrm{~d}, J=8.8 \mathrm{~Hz}, 1 \mathrm{H}, 11-\mathrm{H}), 6.88(\mathrm{~d}, J=8.8 \mathrm{~Hz}, 1 \mathrm{H}, 10-\mathrm{H}), 6.53(\mathrm{~s}$, $1 \mathrm{H}, 3-\mathrm{H}), 6.07$ (s, 1H, $\left.-\mathrm{OCH}_{3} \mathrm{O}-\right), 5.90$ (s, 1H, $\left.-\mathrm{OCH}_{3} \mathrm{O}-\right), 3.90\left(\mathrm{~s}, 3 \mathrm{H}, 8-\mathrm{OCH}_{3}\right), 3.81\left(\mathrm{~s}, 3 \mathrm{H}, 9-\mathrm{OCH}_{3}\right)$, 3.70-3.65 (dd, $J=14.8 \mathrm{~Hz}, J=4.4 \mathrm{~Hz}, 1 \mathrm{H}, 6 \mathrm{a}-\mathrm{H}), 3.18-3.04(\mathrm{~m}, 3 \mathrm{H}, 7-\mathrm{H}, 5-\mathrm{Ha}), 2.66-2.61$ (m, 1H, 5-Hb), $2.59\left(\mathrm{~s}, 3 \mathrm{H},-\mathrm{NCH}_{3}\right), 2.56-2.49(\mathrm{~m}, 1 \mathrm{H}, 4-\mathrm{Ha}), 2.33-2.26(\mathrm{t}, J=14.2 \mathrm{~Hz}, 1 \mathrm{H}, 4-\mathrm{Hb})$. Positive ESI-MS $m / z$ : $340.2[\mathrm{M}+\mathrm{H}]^{+}$.

\subsubsection{Preparation of Dehydrostephanine (4a)}

In a similar manner used in the preparation of $\mathbf{3 a}$, stephanine $(200 \mathrm{mg}, 0.65 \mathrm{mmol})$ was subjected to a dehydrogenation reaction to give compound $4 \mathrm{a}(162 \mathrm{mg}, 81 \%)$ as a yellowish-green solid. 1H-NMR $\left(400 \mathrm{MH}_{\mathrm{Z}}, \mathrm{CDCl}_{3}, \delta\right.$; ppm) $8.56\left(\mathrm{~d}, J=8.4 \mathrm{H}_{\mathrm{Z}}, 1 \mathrm{H}, 11-\mathrm{H}\right), 8.29\left(\mathrm{~d}, J=8.0 \mathrm{H}_{\mathrm{Z}}, 10-\mathrm{H}\right), 7.08(\mathrm{~s}, 1 \mathrm{H}, 9-\mathrm{H})$, $6.96(\mathrm{~s}, \mathrm{H}, 3-\mathrm{H}), 6.93(\mathrm{~s}, \mathrm{H}, 7-\mathrm{H}), 6.21\left(\mathrm{~s}, 2 \mathrm{H},-\mathrm{OCH}_{2} \mathrm{O}-\right), 4.02\left(\mathrm{~s}, 3 \mathrm{H}, 8-\mathrm{OCH}_{3}\right), 3.40-3.37(\mathrm{t}, J=5.6 \mathrm{HZ}$, $\left.2 \mathrm{H}, 5-\mathrm{CH}_{2}\right), 3.27-3.24\left(\mathrm{~m}, 2 \mathrm{H}, 5-\mathrm{CH}_{2}\right), 3.12(\mathrm{~s}, 3 \mathrm{H})$. Positive ESI-MS m/z: $308.2[\mathrm{M}+\mathrm{H}]^{+}$. 


\subsubsection{Preparation of $( \pm)$ Stephanine (4b)}

In a similar manner used for the preparation of $\mathbf{3 b}, \mathbf{4 a}(150 \mathrm{mg}, 0.49 \mathrm{mmol})$ was subjected to a racemization reaction to give compound $4 \mathbf{b}(125 \mathrm{mg}, 83 \%)$ as a yellowish-green solid. $[\alpha]_{D}^{25}: 0^{\circ}(\mathrm{C} 0.2$, $\mathrm{MeOH}) .{ }^{1} \mathrm{H}-\mathrm{NMR}\left(400 \mathrm{MH}_{\mathrm{Z}}, \mathrm{CDCl}_{3}, \delta ; \mathrm{ppm}\right) 7.70(\mathrm{~d}, J=8.0 \mathrm{~Hz}, 1 \mathrm{H}, 11-\mathrm{H}), 7.31-7.26(\mathrm{t}, J=8.0 \mathrm{~Hz}, 1 \mathrm{H}$, $10-\mathrm{H}), 6.85(\mathrm{~d}, J=8.0 \mathrm{~Hz}, 1 \mathrm{H}, 9-\mathrm{H}), 6.58(\mathrm{~s}, 1 \mathrm{H}, 3-\mathrm{H}), 6.10\left(\mathrm{~s}, 1 \mathrm{H},-\mathrm{OCH}_{2} \mathrm{O}-\right), 5.95\left(\mathrm{~s}, 1 \mathrm{H},-\mathrm{OCH}_{2} \mathrm{O}-\right)$, $3.86\left(\mathrm{~s}, 1 \mathrm{H}, 8-\mathrm{OCH}_{3}\right), 3.78-3.74(\mathrm{dd}, J=14.8 \mathrm{~Hz}, J=3.6 \mathrm{~Hz}, 1 \mathrm{H}, 6 \mathrm{a}-\mathrm{H}), 3.40-3.34(\mathrm{~m}, 3 \mathrm{H}, 7-\mathrm{H}, 5 \mathrm{a}-\mathrm{H})$, 2.90-2.83 (m, 1H, 5a-H), $2.80\left(\mathrm{~s}, 3 \mathrm{H},-\mathrm{NCH}_{3}\right), 2.77-2.72(\mathrm{~m}, 1 \mathrm{H}, 4 \mathrm{a}-\mathrm{H}), 2.58-2.51(\mathrm{t}, J=14.4 \mathrm{~Hz}, 1 \mathrm{H}$, 4b-H). Positive ESI-MS $m / z: 310.2[\mathrm{M}+\mathrm{H}]^{+}$.

\subsubsection{Preparation of 11-Methoxy- $N$-Methylisocorydine (5a)}

To a mixture of isocorydine $(200 \mathrm{mg}, 0.59 \mathrm{mmol})$, Tetrabutylammonium bromide $(16 \mathrm{mg}$, $0.03 \mathrm{mmol})$, and $\mathrm{K}_{2} \mathrm{CO}_{3}(163 \mathrm{mg}, 1.18 \mathrm{mmol})$ in anhydrous THF $(10 \mathrm{~mL}) \mathrm{CH}_{3} \mathrm{I}(185 \mathrm{mg}, 1.30 \mathrm{mmol})$ was successively added over a 10-min period and stirred for $8 \mathrm{~h}$ at room temperature. The reaction mixture was condensed and extracted with $\mathrm{CHCl}_{3}$. The combined extracts were dried over anhydrous $\mathrm{Na}_{2} \mathrm{SO}_{4}$, filtered, and concentrated to give a crude product, which was purified by silica gel column chromatography $\left(\mathrm{CH}_{2} \mathrm{Cl}_{2} / \mathrm{MeOH} 50: 1\right)$, yielding compound $5 \mathrm{a}(154 \mathrm{mg}, 71 \%)$ as a white solid. ${ }^{1} \mathrm{H}-\mathrm{NMR}\left(400 \mathrm{MH}_{\mathrm{Z}}, \mathrm{CDCl}_{3}, \delta\right.$; ppm) $6.95\left(\mathrm{~d}, J=8.0 \mathrm{H}_{\mathrm{Z}}, 1 \mathrm{H}, 8-\mathrm{H}\right), 6.84\left(\mathrm{~d}, J=8.4 \mathrm{H}_{\mathrm{Z}}, 1 \mathrm{H}, 9-\mathrm{H}\right)$, $6.66(\mathrm{~s}, 1 \mathrm{H}, 3-\mathrm{H}), 3.88\left(\mathrm{~d}, J=4.0 \mathrm{H}_{\mathrm{Z}}, 6 \mathrm{H}, 1-\mathrm{OCH}_{3}, 2-\mathrm{OCH}_{3}\right), 3.87\left(\mathrm{~s}, 3 \mathrm{H}, 11-\mathrm{OCH}_{3}\right), 3.72\left(\mathrm{~s}, 3 \mathrm{H}, 10-\mathrm{OCH}_{3}\right)$, 3.17-3.10 (m, 1H, 6a-H), 3.04-2.99 (m, 2H, 7-Ha, 5-Ha), 2.87 (d, J = 12.4 Hz, 1H, 7-Hb), 2.69 (d, $\left.J=16.8 \mathrm{H}_{\mathrm{Z}}, 1 \mathrm{H}, 5-\mathrm{Hb}\right), 2.53-2.48\left(\mathrm{~m}, 4 \mathrm{H},-\mathrm{NCH}_{3}, 4-\mathrm{Ha}\right), 2.40-2.33(\mathrm{t}, J=13.0 \mathrm{HZ}, 1 \mathrm{H}, 4-\mathrm{Hb}) .{ }^{13} \mathrm{C}-\mathrm{NMR}$ $\left(100 \mathrm{MH}_{\mathrm{Z}}, \mathrm{CDCl}_{3}, \delta ; \mathrm{ppm}\right) 29.73(\mathrm{t}, \mathrm{C}-4), 23.03(\mathrm{t}, \mathrm{C}-7), 42.94\left(\mathrm{q}, \mathrm{N}-\mathrm{CH}_{3}\right), 53.07\left(\mathrm{q}, \mathrm{N}-\mathrm{CH}_{3}\right), 55.83(\mathrm{q}$, 10- $\left.\mathrm{OCH}_{3}\right), 55.97\left(\mathrm{q}, 2-\mathrm{OCH}_{3}\right), 60.00(\mathrm{t}, \mathrm{C}-5), 60.21\left(\mathrm{q}, 1-\mathrm{OCH}_{3}\right), 60.40\left(\mathrm{q}, 11-\mathrm{OCH}_{3}\right), 111.46(\mathrm{~d}, \mathrm{C}-3)$, 112.72 (d, C-9), 121.63 (s, C-11a). 122.36 (d, C-8), 123.98 (s, C-1a), 123.96 (s, C-7a), 126.18 (s, C-1b), 146.35 (s, C-1), 147.04 (s, C-10), 152.20 (s, C-11), 152.54 (s, C-20). Positive ESI-MS m/z: 370.2 [M + H] $]^{+}$. HR-MS for $\mathrm{C}_{22} \mathrm{H}_{28} \mathrm{NO}_{4}[\mathrm{M}+\mathrm{H}]^{+}$; calcd. 370.2013, found: 370.2026 .

\subsubsection{Preparation of 11-Methoxyisocorydine (5b)}

A solution of isocorydine $(200 \mathrm{mg}, 0.59 \mathrm{mmol})$ in $\mathrm{MeCN}(5 \mathrm{~mL})$ and $\mathrm{MeOH}(5 \mathrm{~mL})$ was treated with $\mathrm{N}, \mathrm{N}$-diisopropylethylamine $(91 \mathrm{mg}, 0.71 \mathrm{mmol})$ and trimethylsilyldiazomethane $(0.36 \mathrm{~mL}, 2 \mathrm{M}$ in hexane), the mixture was stirred at room temperature for $15 \mathrm{~h}$, condensed, and extracted with $\mathrm{CHCl}_{3}$. The combined extracts were dried over anhydrous $\mathrm{Na}_{2} \mathrm{SO}_{4}$, filtered, and concentrated to give a crude product, which was purified by silica gel column chromatography $\left(\mathrm{CHCl}_{3}-\mathrm{MeOH}=80: 1\right)$, yielding compound $5 \mathbf{b}(51 \mathrm{mg}, 24 \%)$ as a colorless oil. ${ }^{1} \mathrm{H}-\mathrm{NMR}\left(400 \mathrm{MH}_{\mathrm{Z}}, \mathrm{CDCl}_{3}, \delta ; \mathrm{ppm}\right) 6.95\left(\mathrm{~d}, J=8.0 \mathrm{H}_{\mathrm{Z}}\right.$, $1 \mathrm{H}, 8-\mathrm{H}), 6.84\left(\mathrm{~d}, J=8.4 \mathrm{H}_{\mathrm{Z}}, 1 \mathrm{H}, 9-\mathrm{H}\right), 6.66(\mathrm{~s}, 1 \mathrm{H}, 3-\mathrm{H}), 3.88\left(\mathrm{~d}, J=4.0 \mathrm{H}_{\mathrm{Z}}, 6 \mathrm{H}, 1-\mathrm{OCH}_{3}, 2-\mathrm{OCH}_{3}\right), 3.87$ $\left(\mathrm{s}, 3 \mathrm{H}, 11-\mathrm{OCH}_{3}\right), 3.72\left(\mathrm{~s}, 3 \mathrm{H}, 10-\mathrm{OCH}_{3}\right), 3.17-3.10(\mathrm{~m}, 1 \mathrm{H}, 6 \mathrm{a}-\mathrm{H}), 3.04-2.99(\mathrm{~m}, 2 \mathrm{H}, 7-\mathrm{Ha}, 5-\mathrm{Ha}), 2.87(\mathrm{~d}$, $\left.J=12.4 \mathrm{H}_{\mathrm{Z}}, 1 \mathrm{H}, 7-\mathrm{Hb}\right), 2.69\left(\mathrm{~d}, J=16.8 \mathrm{H}_{\mathrm{Z}}, 1 \mathrm{H}, 5-\mathrm{Hb}\right), 2.53-2.48\left(\mathrm{~m}, 4 \mathrm{H},-\mathrm{NCH}_{3}, 4-\mathrm{Ha}\right), 2.40-2.33(\mathrm{t}$, $J=13.0 \mathrm{H}_{\mathrm{Z}}, 1 \mathrm{H}, 4-\mathrm{Hb}$ ). Positive ESI-MS $m / z: 356.2[\mathrm{M}+\mathrm{H}]^{+}$. HR-MS for $\mathrm{C}_{21} \mathrm{H}_{25} \mathrm{NO}_{4}[\mathrm{M}+\mathrm{H}]^{+}$; calcd. 356.1856, found: 356.1864 .

\subsubsection{Preparation of 11-Ethoxyisocorydine (5c)}

A mixture of isocorydine ( $200 \mathrm{mg}$, $0.59 \mathrm{mmol})$, Tetrabutylammonium bromide ( $16 \mathrm{mg}, 0.03 \mathrm{mmol})$, and $\mathrm{K}_{2} \mathrm{CO}_{3}(163 \mathrm{mg}, 1.18 \mathrm{mmol})$ in anhydrous THF $(10 \mathrm{~mL})$ was successively added $\mathrm{CH}_{3} \mathrm{CH}_{2} \mathrm{I}$ (203 $\mathrm{mg}, 1.30 \mathrm{mmol}$ ) over a 10-min period and stirred for $8 \mathrm{~h}$ at room temperature. The reaction mixture was condensed and extracted with $\mathrm{CHCl}_{3}$. The combined extracts were dried over anhydrous $\mathrm{Na}_{2} \mathrm{SO}_{4}$, filtered, and concentrated to get a crude product, which was purified by silica gel column chromatography $\left(\mathrm{CH}_{2} \mathrm{Cl}_{2} / \mathrm{MeOH} 50: 1\right)$, yielding compound $5 \mathrm{c}(80 \mathrm{mg}, 23 \%)$ as a colorless oil. ${ }^{1} \mathrm{H}-\mathrm{NMR}$ $\left(400 \mathrm{MH}_{\mathrm{Z}}, \mathrm{CDCl}_{3}, \delta ; \mathrm{ppm}\right) 6.95\left(\mathrm{~d}, J=8.0 \mathrm{H}_{\mathrm{Z}}, 1 \mathrm{H}, 8-\mathrm{H}\right), 6.83\left(\mathrm{~d}, J=8.0 \mathrm{H}_{\mathrm{Z}}, 1 \mathrm{H}, 9-\mathrm{H}\right), 6.66(\mathrm{~s}, 1 \mathrm{H}, 3-\mathrm{H})$, $3.87\left(\mathrm{~d}, J=2.8 \mathrm{H}_{\mathrm{Z}}, 6 \mathrm{H}, 1-\mathrm{OCH}_{3}, 2-\mathrm{OCH}_{3}\right), 3.84-3.79(\mathrm{~m}, 1 \mathrm{H}, 6 \mathrm{a}-\mathrm{H}), 3.66\left(\mathrm{~s}, 3 \mathrm{H}, 10-\mathrm{OCH}_{3}\right), 3.19-3.14$ (m, 1H, 7-Ha), 3.05-2.98 (m, 2H,11- $\left.\mathrm{CH}_{2}\right), 2.87-2.83(\mathrm{~m}, 1 \mathrm{H}, 7-\mathrm{Hb}), 2.71-2.67$ (m 1H, 5- Ha), 2.54 (s, 3H, 
$\left.-\mathrm{NCH}_{3}\right), 2.50-2.47(\mathrm{~m}, 4-\mathrm{Ha}), 2.40-2.34\left(\mathrm{t}, 1 \mathrm{H}, J=12.8 \mathrm{H}_{\mathrm{Z}}, 4-\mathrm{Hb}\right), 1.14-1.10\left(\mathrm{t}, J=7.0 \mathrm{H}_{\mathrm{Z}}, 3 \mathrm{H}, 11-\mathrm{CH}_{3}\right)$. ${ }^{13} \mathrm{C}-\mathrm{NMR}\left(100 \mathrm{MH}_{\mathrm{Z}}, \mathrm{CDCl}_{3}, \delta\right.$; ppm) 15.79 (q, 11- $\left.\mathrm{CH}_{2} \mathrm{CH}_{3}\right), 25.87$ (t, C-7), 33.34 (t, C-4). 56.21 (q, $\left.10-\mathrm{OCH}_{3}\right), 60.96\left(\mathrm{q}, 1-\mathrm{OCH}_{3}\right), 61.14\left(\mathrm{q}, 2-\mathrm{OCH}_{3}\right), 68.89\left(\mathrm{t}, 11-\mathrm{CH}_{2} \mathrm{CH}_{3}\right), 111.41$ (d, C-3), 112.72 (d, C-9), 122.04 (d, C-8), 124.00 (C-7a), 125.01 (s, C-1a), 127.00 (s, C-1b), 146.89 (s, C-1), 147.04 (s, C-10), 152.82 (s, C-11), 153.42 (s, C-2). Positive ESI-MS m/z: $370.2[\mathrm{M}+\mathrm{H}]^{+}$. HR-MS for $\mathrm{C}_{22} \mathrm{H}_{27} \mathrm{NO}_{4}[\mathrm{M}+\mathrm{H}]^{+}$; calcd. 370.2013, found: 370.2022 .

\subsubsection{Preparation of N-Methylisocorydine (5d)}

In a similar manner used in the preparation of $\mathbf{2 d}$, isocorydine $(200 \mathrm{mg}, 0.59 \mathrm{mmol})$ was subjected to a $\mathrm{N}$-methylation reaction to give compound $5 \mathrm{~d}\left(183 \mathrm{mg}, 88 \%\right.$ yield) as a white solid. ${ }^{1} \mathrm{H}-\mathrm{NMR}$ $\left(400 \mathrm{MH}_{\mathrm{Z}}, \mathrm{CDCl}_{3}, \delta ; \mathrm{ppm}\right) 8.60(\mathrm{~s}, 1 \mathrm{H}, 11-\mathrm{OH}), 7.01(\mathrm{~d}, J=8.0 \mathrm{~Hz}, 1 \mathrm{H}, 8-\mathrm{H}), 6.89(\mathrm{~d}, J=8.0 \mathrm{~Hz}, 2 \mathrm{H}$, 9-H), $6.86(\mathrm{~s}, 1 \mathrm{H}, 3-\mathrm{H}), 4.77-4.73\left(\mathrm{dd}, J=12.0 \mathrm{H}_{\mathrm{Z}}, J=5.2 \mathrm{H}_{\mathrm{Z}}, 1 \mathrm{H}, 6 \mathrm{a}-\mathrm{H}\right), 4.24(\mathrm{~d}, J=13.2,1 \mathrm{H}, 5 \mathrm{a}-\mathrm{H})$, $3.96\left(\mathrm{~s}, 3 \mathrm{H}, 1-\mathrm{OCH}_{3}\right), 3.89\left(\mathrm{~s}, 3 \mathrm{H}, 2-\mathrm{OCH}_{3}\right), 3.76\left(\mathrm{~s}, 3 \mathrm{H}, 10-\mathrm{OCH}_{3}\right), 3.74\left(\mathrm{~s}, 3 \mathrm{H},-\mathrm{NCH}_{3}\right), 3.65-3.58(\mathrm{~m}$, 2H, 7a-H), 3.54-3.41 (m, 2H, 5b-H, 7a-H), 3.33 (s, 3H, -NCH 3 ), 3.11-3.07 (m, 1H, 4-Ha), 2.88-2.81 (t, $\left.J=12.0 \mathrm{H}_{\mathrm{Z}}, 1 \mathrm{H}, 4-\mathrm{Hb}\right)$. Positive ESI-MS $m / z: 356.2[\mathrm{M}]^{+}$.

\subsubsection{Preparation of (Z)-N-2,3-Dimethoxybenzylidene-3,4-Dimethoxy-2-Phenyl-Ethanamine (6a)}

A mixture of 2-(3,4-dimethoxy-phenyl)-ethylamine ( $1 \mathrm{~g}, 5.5 \mathrm{mmol})$ and 2,3-dimethoxy-benzoic acid $(1.1 \mathrm{~g}, 6.1 \mathrm{mmol})$ in methylbenzene $(50 \mathrm{~mL})$ was heated to $120^{\circ} \mathrm{C}$ for $8 \mathrm{~h}$. The reaction mixture was condensed and extracted with EtOAC. The combined extracts were washed with water three times, dried over anhydrous $\mathrm{Na}_{2} \mathrm{SO}_{4}$, filtered, and concentrated. The crude product was drawn off by a vacuum pump over $4 \mathrm{~h}$ to give compound $6 \mathrm{a}(1.78 \mathrm{~g}, 92 \%$ Purity, 91\% yield) as a brown-red oil. ${ }^{1} \mathrm{H}-\mathrm{NMR}\left(400 \mathrm{MH}_{\mathrm{Z}}, \mathrm{CDCl}_{3}, \delta\right.$; ppm) $7.54\left(\mathrm{~d}, J=7.6 \mathrm{H}_{\mathrm{Z}} 1 \mathrm{H}, \mathrm{N}-\mathrm{CH}_{2} \mathrm{CH}_{2} \mathrm{Ph}-2 \mathrm{H}\right), 7.09-7.05$ (t, $\left.J=8.0 \mathrm{H}_{\mathrm{Z}}, 1 \mathrm{H}, \mathrm{N}-\mathrm{CH}_{2} \mathrm{Ph}-4 \mathrm{H}\right), 6.96\left(\mathrm{~d}, J=8.0 \mathrm{H}_{\mathrm{Z}}, 1 \mathrm{H}, \mathrm{N}-\mathrm{CH}_{2} \mathrm{CH}_{2} \mathrm{Ph}-5 \mathrm{H}\right), 6.76\left(\mathrm{~d}, J=12.0 \mathrm{H}_{\mathrm{Z}}\right.$, $\left.3 \mathrm{H}, \mathrm{N}-\mathrm{CH}_{2} \mathrm{CH}_{2} \mathrm{Ph}-6 \mathrm{H}, \mathrm{N}-\mathrm{CH}_{2} \mathrm{Ph}-3 \mathrm{H}, \mathrm{N}-\mathrm{CH}_{2} \mathrm{Ph}-5 \mathrm{H}\right), 3.90-3.88\left(\mathrm{~m}, 1 \mathrm{H}, \mathrm{N}-\mathrm{CH}_{2 \beta}\right), 3.87-3.76(\mathrm{~m}, 12 \mathrm{H}$, $\left.4 \times-\mathrm{OCH}_{3}\right), 2.98-2.94\left(\mathrm{t}, J=7.0 \mathrm{H}_{\mathrm{Z}}, 2 \mathrm{H}, \mathrm{N}-\mathrm{CH}_{2 \alpha}\right)$. Positive ESI-MS $m / z: 330.2[\mathrm{M}+\mathrm{H}]^{+}$.

\subsubsection{Preparation of N-2,3-Dimethoxybenzyl-3,4-Dimethoxy-2-Phenylethanamine (6b)}

Amixture of $6 \mathrm{a}(1.5 \mathrm{~g}, 4.6 \mathrm{mmol})$ and $\mathrm{Pd} / \mathrm{C}(5 \%, 150 \mathrm{mg})$ in $\mathrm{MeOH}(50 \mathrm{~mL})$ was stirred under a hydrogen atmosphere $(1 \mathrm{bar})$ for $8 \mathrm{~h}$. The $\mathrm{MeOH}$-insoluble material was filtered off and the filtrate was evaporated to give a crude product, which was purified by silica gel column chromatography $\left(\mathrm{CH}_{2} \mathrm{Cl}_{2}\right.$ /petroleum ether 1:1), yielding compound $\mathbf{6 b}(1.3 \mathrm{~g}, 87 \%)$ as a yellow oil. ${ }^{1} \mathrm{H}-\mathrm{NMR}\left(400 \mathrm{MH}_{\mathrm{Z}}\right.$, $\left.\mathrm{CDCl}_{3}, \delta ; \mathrm{ppm}\right), 7.01-6.97\left(\mathrm{t}, J=8.0 \mathrm{H}_{\mathrm{Z}}, 1 \mathrm{H}, \mathrm{N}-\mathrm{CH}_{2} \mathrm{Ph}-4 \mathrm{H}\right), 6.83\left(\mathrm{~d}, J=6.4 \mathrm{H}_{\mathrm{Z}}, 2 \mathrm{H}, \mathrm{N}-\mathrm{CH}_{2} \mathrm{CH}_{2} \mathrm{Ph}-5 \mathrm{H}\right.$,

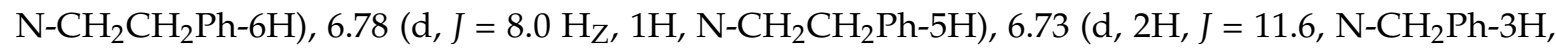
$\left.\mathrm{N}-\mathrm{CH}_{2} \mathrm{Ph}-5 \mathrm{H}\right), 3.84-3.77\left(\mathrm{~m}, 12 \mathrm{H}, 4 \times-\mathrm{OCH}_{3}\right), 2.87-2.83\left(\mathrm{t}, J=7.0 \mathrm{H}_{\mathrm{Z}}, 2 \mathrm{H}, \mathrm{N}-\mathrm{CH}_{2 \alpha}\right), 2.78-2.74(\mathrm{t}$, $\left.J=6.8 \mathrm{H}_{\mathrm{Z}}, 2 \mathrm{H}, \mathrm{N}-\mathrm{CH}_{2 \beta}\right), 1.89\left(\mathrm{~s}, 2 \mathrm{H}, \mathrm{N}-\mathrm{CH}_{2}\right)$. Positive ESI-MS $m / z: 310.2[\mathrm{M}+\mathrm{H}]^{+}$.

\subsubsection{Preparation of N-Methyl-N-2,3-Dimethoxybenzyl-3,4-Dimethoxy-2-Phenyl-Ethanamine (6c)}

To a mixture of $6 \mathbf{b}(1.2 \mathrm{~g}, 3.6 \mathrm{mmol})$ and $\mathrm{K}_{2} \mathrm{CO}_{3}(1.0 \mathrm{~g}, 7.2 \mathrm{mmol})$ in anhydrous THF $(20 \mathrm{~mL}), \mathrm{CHI}$ (610.6 mg, $4.3 \mathrm{mmol}$ ) was slowly added under an ice-bath over a 10-min period. The solution was stirred for $4 \mathrm{~h}$ at room temperature, condensed, and extracted with EtOAC. The combined extracts were dried over anhydrous $\mathrm{Na}_{2} \mathrm{SO}_{4}$ and filtered, and the filtrate was concentrated to give a crude product, which was purified by silica gel column chromatography $\left(\mathrm{CH}_{2} \mathrm{Cl}_{2}\right.$ /petroleum ether 10:1), yielding compound $6 \mathrm{c}\left(950 \mathrm{mg}, 76 \%\right.$ yield) as a colorless oil. ${ }^{1} \mathrm{H}-\mathrm{NMR}\left(400 \mathrm{MH}_{\mathrm{Z}}, \mathrm{CDCl}_{3}, \delta ; \mathrm{ppm}\right)$ $7.06-7.00\left(\mathrm{dd}, 2 \mathrm{H}, J=9.6 \mathrm{H}_{\mathrm{Z}}, J=4.8 \mathrm{H}_{\mathrm{Z}}, \mathrm{N}-\mathrm{CH}_{2} \mathrm{CH}_{2} \mathrm{Ph}-5 \mathrm{H}, \mathrm{N}-\mathrm{CH}_{2} \mathrm{CH}_{2} \mathrm{Ph}-6 \mathrm{H}\right), 6.86(\mathrm{t}, 1 \mathrm{H}, J=4.2 \mathrm{HZ}$, $\left.\mathrm{N}-\mathrm{CH}_{2} \mathrm{Ph}-4 \mathrm{H}\right), 6.78\left(\mathrm{~d}, 1 \mathrm{H}, J=8.4, \mathrm{~N}_{-} \mathrm{CH}_{2} \mathrm{CH}_{2} \mathrm{Ph}-2 \mathrm{H}\right), 6.73\left(\mathrm{~d}, 2 \mathrm{H}, J=7.2, \mathrm{~N}_{-} \mathrm{CH}_{2} \mathrm{Ph}-5 \mathrm{H}, \mathrm{N}-\mathrm{CH}_{2} \mathrm{Ph}-3 \mathrm{H}\right)$, 3.86-3.82 (m, $\left.12 \mathrm{H}, 4 \times-\mathrm{OCH}_{3}\right), 3.74\left(\mathrm{~s}, 2 \mathrm{H}, \mathrm{N}-\mathrm{CH}_{2}\right), 2.87\left(\mathrm{t}, 2 \mathrm{H}, J=7.2, \mathrm{~N}-\mathrm{CH}_{2 \alpha}\right), 2.77-2.71(\mathrm{~m}, 2 \mathrm{H}$, $\left.\mathrm{N}-\mathrm{CH}_{2 \beta}\right), 2.37(\mathrm{~s}, 3 \mathrm{H})$. Positive ESI-MS $m / z: 346.2[\mathrm{M}+\mathrm{H}]^{+}$. 


\subsection{Pharmacological Evaluation}

\subsubsection{Materials}

Verapamil hydrochloride (Shanghai Harvest Pharmaceutical Co., Ltd., Shanghai, China), lidocaine hydrochloride (Shanghai ZhaohuiPharmaceutical Co., Ltd., Shanghai, China), isocorydine, crebanine, and stephanine were used as positive control groups. Normal saline (NS) (Kunming Nanjiang Pharmaceutical Co., Ltd., Kunming, China) was used as negative control group. Other chemicals used—chloral hydrate, barium chloride, chloroform, sodium hydroxide, and hydrochloric acid were of analytical grade.

All aporphine alkaloid derivatives were used for the tested drug groups, and were synthesized, purified, and determined according to Sections 3.1.2-3.1.20 in this paper. The compounds were dissolved in $10 \%$ hydrochloric acid solution and were adjusted to $\mathrm{pH} 5-7$ with $40 \%$ sodium hydroxide.

\subsubsection{Animals}

The experiments were carried out on Kunming mice (28-35 g) and SD rats (180-210 g), which were provided by Hunan SJA Laboratory Animal Co., Ltd. (SYXK (Dian) K 2011-0011, Changsha, China). Half of the animals were male and half were female, and they were housed in a controlled environment (temperature $22 \pm 1{ }^{\circ} \mathrm{C} ; 60 \% \pm 10 \%$ humidity; in a 12/12 h light-dark cycle) with free access to standard pellet artificial diet and tap water. All animal experiments performed were in compliance with the Animal Experimental Care and Ethic Committee of Yunnan University of Traditional Chinese Medicine.

Determination of the dosage for tested drugs: The animals were first given $5 \mathrm{mg} / \mathrm{kg}$ of tested drugs, based on the effective dose of crebanine in mice and rat [7]. The dosage was reduced or increased according to the exhibited symptoms of poisoning, or death, and the antiarrhythmic effect on the animals.

\subsubsection{Statistical Analyses}

Data are expressed as the means \pm SD and incidence ratio. Statistical significance was calculated using the Chi-square test. Differences were considered significant when $p<0.05 . \mathrm{LD}_{50}$ was determined using a related formulate of up-and-down procedure (UDP) [28].

\subsubsection{Antiarrhythmic Activity Test of Aporphine Derivatives in a Mouse Model of Ventricular} Fibrillation Induced by $\mathrm{CHCl}_{3}$

Mice were randomly divided into a negative control group (NS), 4 positive control groups (verapamil hydrochloride, crebanine, iscorydine, and stephanine), and 19 tested groups for aporphine derivatives (Figure 1). Tested drugs were injected though the caudal vein at a chosen dose. Five minutes later, each mouse was placed in a 500-mL inverted beaker, which contained a cotton ball that had been soaked with $1 \mathrm{~mL}$ of chloroform, and then were removed immediately after respiratory arrest. The chest of the asphyxiated mouse was opened in order to observe the condition of ventricular fibrillation (VF) [7,29]. The occurrence ratios of VF in mice are listed in Figure 1.

3.2.5. Anti-Arrhythmic Activity of Five Kinds of Aporphine Derivatives in a Rat Model of Arrhythmia Induced by $\mathrm{BaCl}_{2}$

Rats were randomly divided into 10 groups: an NS group, 4 groups of positive control (lidocaine, crebanine, iscorydine and stephanine) groups, and 5 tested groups of active derivatives ( $2 \mathbf{a}-\mathbf{d}$ and 4a) (Table 1). First, rats were anesthetized with 10\% choral hydrate (ip, $300 \mathrm{mg} / \mathrm{kg}$ ), fixed on their backs and connected to a physiological signal acquisition system in order to record normal II lead electrocardiogram (ECG). Then, a barium chloride solution was injected into the caudal vein of each rat $(4 \mathrm{mg} / \mathrm{kg}$, at a volume of $1 \mathrm{~mL} / \mathrm{kg}$ ) to trigger arrhythmia. Three minutes later, rats were injected with different treatments though the lingual vein at a certain doses. Then, ECG was recorded. The number 
of rats that recovered to a normal sinus rhythm, the duration needed to recover, and number of rats that maintained normal rhythm for more than $3 \mathrm{~min}, 5 \mathrm{~min}$, and $20 \mathrm{~min}$, in each group, were calculated [7,29] (Table 1).

\subsubsection{Acute Toxicity Test in Mice}

Mice were injected with the test compounds via the caudal vein at a certain dose. The $D_{m}$ (100\% death) and $D_{n}(0 \%$ death) of the compounds were found in preliminary tests; then, 5- 6 dose groups $(n=10)$ of the compounds were set up, according to the requirements of the up-and-down procedure (UDP) method, death number was recorded and $\mathrm{LD}_{50}$ was determined [28].

\section{Conclusions}

In this study, derivatives of three kinds of aporphine alkaloids, crebanine, isocorydine, and stephanine, were designed and synthesized through the reactions of ring-opening, $N$-substitution, demethylation, methylation, acetylation, quaternization, and dehydrogenation. The use of NBS for the bromination reaction was successfully applied to the synthesis of the three kinds of bromocrebanines. Among these derivatives, compound $\mathbf{2} \mathbf{b}$, dibromocrebanine, proved to be the most promising candidate, showing maximum potency against arrhythmia and minimum toxicity compared to the other compounds prepared in this family. Derivatives $\mathbf{2 a}, \mathbf{2 c}, \mathbf{2 d}$, and $\mathbf{4 a}$ also displayed impressive potency. Finally, derivative 1d exhibited a lower, though still significant, activity.

The relationship of the structure-antiarrhythmic activities of aporphines are summarized as: (1) C-1,C-2-methylenedioxy group on ring A of aporphines increases the planar configuration of molecules and plays an important role in both activity and toxicity; (2) a closed structure of the B ring is essential for both antiarrhythmic efficacy and toxicity; additionally, $N$-quaternization of ring $\mathrm{B}$ could increase toxicity; (3) levoduction of $6 \mathbf{a}$ in ring $C$ is an active group; and (4) 8-, 9-, and 10-methoxy groups on ring $\mathrm{D}$ is an important functional groups. Further explorations are underway to evaluate the biological activities and the ion channel mechanisms of these aporphine derivatives.

Acknowledgments: The National Natural Science Foundation of China (81260651) and the Science Foundation of Education Department of Yunnan Province (2015J102) are gratefully acknowledged for their financial support. We acknowledge members of Minglong Yuan's lab, Yunnan Minzu University, for chemical modifications. We also thank. Qing Zhao, Hongping He and Aixue Zuo for chemical structure analyses, and Jia Chen for language assistance.

Author Contributions: Yunshu Ma and Hui Wang conceived and designed the experiments; Hui Wang and Shujun Kong performed the experiments; Hui Wang, Zixian Yang and Hongmei Wang analyzed the data; Qiuyan Huang, Jingyu Li and Cheng Chen contributed reagents and materials; Yunshu Ma, Hui Wang and Xin Cheng wrote the paper.

Conflicts of Interest: The authors declare no conflict of interest.

\section{References}

1. Scholz, H. Classification and Mechanism of Action of Antiarrhythmic Drugs. Fundam. Clin. Pharmacol. 1994, 8, 385-390. [CrossRef] [PubMed]

2. Podrid, P.J. Aggravation of Arrhythmia by Antiarrhythmic Drugs (Proarrhythmia). Cardiac. Electrophysiol. Clin. 2010, 2, 459-470. [CrossRef]

3. Yang, Q.; Wang, X.J.; Tang, Y.-Q.; You, Q.-D. The Research Practice of Anti-arrhythmic Agents Targeting on Potassium Ion Channel. Acta Pharm. Sin. 2011, 46, 12-18.

4. Yao, S.B.; Hao, J.H.; Li, X.G.; Fan, L.; Liu, Y. Anti-arrhythmic Targets of Natural Products: Research Advances. Chin. J. Pharmacol. Toxicol. 2016, 2, 151-157.

5. Ren, J.H.; Chen, L.H. The Pharmacological Action and Clinical Application of Isocorydine. Chin. Pharm. 1999, 7, 10-11.

6. Su, Y.H.; Li, H.L. Effective Comparison of L-dicentrine on Arrhythmia Caused by Different Kinds of Cardiac Glycoside. Chin. J. Ethnomed. Ethnopharm. 2002, 58, 301-302. 
7. Yu, Z.F.; Ma, Y.S.; Zhao, Z.X.; Wang, F.C. Antiarrhymic Effects of Crebanine. Chin. J. Chin. Mat. Med. 1992, 11, 685-687.

8. Huang, J.X.; Chen, Y. Studies on the Alkaloids of Stephania Species. I. Isolation and identification of alkaloids from Stephniaepigeae. Acta Pharm. Sin. 1979, 14, 612-616.

9. Moreno, L.; Cabedo, N.; Ivorra, M.D.; Sanz, M.J.; Castel, A.L.; Álvarez, C.; Cortes, D. 3,4-Dihydroxy- and 3,4-methylenedioxy-phenanthrene-type alkaloids with high selectivity for D2 dopamine receptor. Bioorg. Med. Chem. Lett. 2013, 23, 4824-4827. [CrossRef] [PubMed]

10. Kathofer, S.; Thomas, D.; Karle, C.A. The Novel Antiarrhythmic Drug Dronedarone: Comparison with Amiodarone. Cardiovasc. Drug Rev. 2005, 23, 217-230. [CrossRef] [PubMed]

11. Touboul, P.; Brugada, J.; Capucci, A.; Touboul, P.; Crijns, N.; Edvardsson, H.J.G.M.; Hohnloser, S.H. Dronedarone for Prevention of Atrial Fibrillation: A Dose-ranging Study. Eur. Heart J. 2003, 24, 1481-1487. [CrossRef]

12. Ehrlich, J.R.; Hohnloser, S.H. Milestones in the Management of Atrialfibrillation. Heart Rhythm. 2009, 6, 62-67. [CrossRef] [PubMed]

13. Li, W.L.; Yu, Z.F.; Lin, Q.; Ma, Y.S.; Luo, Q.Y. Effects of Crebanine on Arrhythmias Induced by Ischemia and Reperfusion in Rats. Chin. Pharmacol. Bull. 2005, 21, 1019-1020.

14. Ma, Y.S.; Wu, H.P.; Zhang, Z.L. Acute Toxicity and Antiarrhythmia Effect of Crebanine. Chin. J. Mod. Appl. Pharm. 2005, 22, 368-369.

15. Lei, Z.B. Adverse Reactions and Interactions of the Antiarrhythmic Drug Dronedarone. Chin. J. New. Drugs 2012, 21, 1826-1830.

16. Zhao, Q.Z.; Zhao, Y.M. Progress in Biological Activities of Aporphinoid Alkaloids. Nat. Prod. Res. Dev. 2006, 18, 316-324.

17. Gao, Y.; Zong, R.; Campbell, A.; Kula, N.S.; Baldessarini, R.J.; Neumeyer, J.L. Synthesis and Dopamine Agonist and Antagonist Effects of R-(-)- and S-(+)-11-hydroxy-N-n-propylnoraporphine. J. Med. Chem. 1988, 31, 1392-1396. [CrossRef] [PubMed]

18. Hedberg, M.H.; Johansson, A.M.; Nordvall, G.; Yliniemelä, A.; Li, H.B.; Martin, A.R.; Hjorth, S.; Unelius, L.; Sundell, S.; Hacksell, U. (R)-11-Hydroxy- and (R)-11-Hydroxy-10-methylaporphine: Synthesis, Pharmacology, and Modeling of D2A and 5-HT1A Receptor Interactions. J. Med. Chem. 1995, 38, 647-658. [CrossRef] [PubMed]

19. Neumeyer, J.L.; Granchelli, F.; Little, A.D.; Aporphines, V.I. A novel synthesis of 7-hydroxyaporphine, 7-hydroxynoraporphine and 6a,7-dehydronoraporphine Granchelli. Tetrahedron Lett. 1970, 11, 5261-5264. [CrossRef]

20. Wang, X.K.; Zhao, T.F. Distribution and Biological Activities of Alkaloids in plants of Genus Stephania. Chin. Pharm. J. 1990, 25, 3-6.

21. Gao, Y.G.; Baldessarini, R.J.; Kula, N.S.; Neumeyer, J.L. Synthesis and Dopamine Receptor Affinities of Enantiomers of 2-substituted Apomorphines and Their N-n-propyl Analogs. J. Med. Chem. 1990, 33, 1800-1805. [CrossRef] [PubMed]

22. Manabu, N.; Kiyoharu, N.; Kaoru, F.; Eiichi, F.J. Demethylation of Methyl Ethers of Alcohol and Phenol with an Aluminum Halide-Thiol System. Org. Chem. 1980, 45, 4275-4277.

23. Gao, Y.; Ram, V.J.; Campbell, A.; Kula, N.S.; Baldessarini, R.J.; Neumeyer, J.L. Synthesis and structural requirements of $N$-substituted norapomorphines for affinity and activity at dopamine D-1, D-2, and agonist receptor sites in rat brain. J. Med. Chem. 1990, 33, 39-44. [CrossRef]

24. Shamma, M.; Slusarchyk, W.A. The Aporphine Alkaloids. Chem. Rev. 1964, 64, 59-79. [CrossRef]

25. Nakamura, S.; Nakashima, S.; Tanabe, G.; Oda, Y.; Yokota, N.; Fujimoto, K.; Matsumoto, T.; Sakuma, R.; Ohta, T.; Ogawa, K. Alkaloid constituents from flower buds and leaves of sacred lotus (Nelumbonucifera, Nymphaeaceae) with melanogenesis inhibitory activity in B16 melanoma cells. Bioorg. Med. Chem. Lett. 2013, 21,779-879. [CrossRef] [PubMed]

26. Chen, Y.; Fang, S.D.; Liang, D.; Jiang, F.Y. Studies on the Alkaloids of Stephania Yunnanensis. Acta Bot. Sin. 1989, 31, 296-299.

27. Zuo, A.X.; Ma, Y.S.; Rao, G.X.; Chin, J. Akaloids from Roots of Stephania Mashanica. Chin. Mat. Med. 2013, 4, 574-577. 
28. OECD. Acute oral toxicity-up-and-down procedure. In OECD Guidelines for the Testing of Chemicals; Organization for Economic Cooperation and Development: Paris, France, 2001; Volume 425, pp. 1-26.

29. Li, Y.K. Experimental Methodology of TCM Pharmacology; Shanghai Scientific and Tchnical Press: Shanghai, China, 2006; pp. 1001-1007.

Sample Availability: The compounds $\mathbf{1 a}, \mathbf{2 a}, \mathbf{2 b}, \mathbf{1 e}, \mathbf{2 d}$ and $\mathbf{6 b}$ are avilable, other compounds are not provided from us.

(C) 2016 by the authors; licensee MDPI, Basel, Switzerland. This article is an open access article distributed under the terms and conditions of the Creative Commons Attribution (CC-BY) license (http://creativecommons.org/licenses/by/4.0/). 